\title{
The Burden of Human Papillomavirus Infections and Related Diseases in Sub-Saharan Africa
}

\author{
Hugo De Vuyst ${ }^{\mathrm{a}}$, Laia Alemany ${ }^{\mathrm{b}, \mathrm{c}}$, Charles Lacey ${ }^{\mathrm{d}}$, Carla J. Chibwesha ${ }^{\mathrm{e}}$, Vikrant \\ Sahasrabuddhe ${ }^{f}$, Cecily Banurag, Lynette Denny ${ }^{\mathrm{h}}$, and Groesbeck P. Parham ${ }^{\mathrm{i},{ }^{*}}$
}

anfection and Cancer Epidemiology Group, International Agency for Research on Cancer (WHOIARC), Lyon, France bUnit of Infections and Cancer (UNIC), Cancer Epidemiology Research Program (CERP), Institut Català d'Oncologia - Catalan Institute of Oncology (ICO), L'Hospitalet de Llobregat (Barcelona), Spain ' $\mathrm{CIBER}$ en Epidemiología y Salud Pública (CIBERESP), Spain ${ }^{d}$ Centre for Immunology and Infection, Hull York Medical School, University of York, York, UK eUniversity of North Carolina at Chapel Hill School of Medicine, Chapel Hill, North Carolina, U.S.A

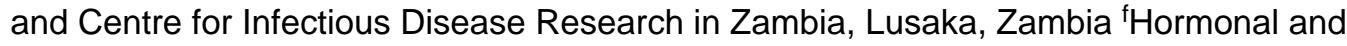
Reproductive Epidemiology Branch, Division of Cancer Epidemiology and Genetics, National Cancer Institute, National Institutes of Health, Bethesda, MD, USA 9Department of Child Health and Development Centre, Makerere University College of Health Sciences, Kampala, Uganda hDepartment of Obstetrics and Gynaecology and Institute of Infectious Diseases and Molecular Medicine, University of Cape Town, Groote Schuur Hospital, Observatory, Cape Town, South Africa 'Department of Obstetrics and Gynecology, UNC Global Women's Health, University of North Carolina - Chapel Hill, North Carolina, USA

\section{Abstract}

Despite the scarcity of high quality cancer registries and lack of reliable mortality data, it is clear that human papillomavirus (HPV)-associated diseases, particularly cervical cancer, are major causes of morbidity and mortality in sub-Saharan Africa (SSA). Cervical cancer incidence rates in SSA are the highest in the world and the disease is the most common cause of cancer death among women in the region. The high incidence of cervical cancer is a consequence of the inability of most countries to either initiate or sustain cervical cancer prevention services. In addition, it appears that the prevalence of HPV in women with normal cytology is higher than in more developed areas of the world, at an average of $24 \%$. There is, however, significant regional variation in SSA, with the highest incidence of HPV infection and cervical cancer found in Eastern and Western Africa. It is expected that, due to aging and growth of the population, but

(C) 2013 Published by Elsevier Ltd.

*Corresponding author. Tel.: +260 978124392 (Zambia)/+1 2059239995 (USA). groesbeck.parham@cidrz.org (G.P. Parham). This article forms part of a regional report entitled "Comprehensive Control of HPV Infections and Related Diseases in the SubSaharan Africa Region" Vaccine Volume 31, Supplement 5, 2013. Updates of the progress in the field are presented in a separate monograph entitled "Comprehensive Control of HPV Infections and Related Diseases" Vaccine Volume 30, Supplement 5, 2012.

Disclosed potential conflict of interest

HDV, CL, CJC, VS, CB, GPP: Have disclosed no potential conflicts of interest.

Appendix A. Supplementary data

Supplementary data associated with this article can be found, in the online version, at http://dx.doi.org/10.1016/j.vaccine.2012.07.092. 
also to lack of access to appropriate prevention services and the concomitant human immunodeficiency virus (HIV)/acquired immunodeficiency syndrome (AIDS) epidemic, cervical cancer incidence and mortality rates in SSA will rise over the next 20 years. HPV16 and 18 are the most common genotypes in cervical cancer in SSA, although other carcinogenic HPV types, such as HPV45 and 35, are also relatively more frequent compared with other world regions. Data on other HPV-related anogenital cancers including those of the vulva, vagina, anus, and penis, are limited. Genital warts are common and associated with HPV types 6 and 11. HIV infection increases incidence and prevalence of all HPV-associated diseases. Sociocultural determinants of HPV-related disease, as well as the impact of forces that result in social destabilization, demand further study. Strategies to reduce the excessive burden of HPV-related diseases in SSA include age-appropriate prophylactic HPV vaccination, cervical cancer prevention services for women of the reproductive ages, and control of HIV/AIDS.

\section{Keywords}

HPV epidemiology; Cervical cancer; Anogenital cancers; Genital warts; Sub-Saharan Africa

\section{Introduction}

While communicable diseases, such as tuberculosis and human immunodeficiency virus (HIV)/acquired immunodeficiency syndrome (AIDS), maternal mortality and malaria, receive the most attention in terms of the burden of disease in Africa, cancer is largely under-recognized as a significant health problem. Yet, the burden of cancer is increasing in sub-Saharan Africa (SSA) [1]. In 2008, it was estimated that there were 551,221 new cancer cases and 420,978 deaths in SSA [2]. These numbers are estimated to double in the next 20 years due to aging and growth of the overall population. The data from the GLOBOCAN 2008 database of the International Agency for Research on Cancer (IARC, Lyon, France) present estimates of the incidence of, and mortality from, 27 major cancers in 184 countries or territories in 2008 [2]. Invasive cervical cancer (ICC) is the most common cancer diagnosed in women in SSA, with 75,141 new cases reported per year, and also the leading cause of cancer death at 50,233 deaths [2]. Rates of cervical cancer vary considerably in different sub-regions; however, cervical cancer ranks first or second (after breast cancer) in all individual SSA countries and sub-regions. Guinea, Zambia, Tanzania, Malawi, and Mozambique have some of the highest ICC incidence rates in the world at $>50 / 100,000$ women. Of note, the rate of cervical cancer in the United States of America (USA) between 1947 and 1949, prior to the introduction of the Pap smear in the 1960s, was 40/100,000 in white women and 73/100,000 in black women [1]. In contrast, breast cancer is the most frequent cancer in women inmore developed countries. In several SSA countries, breast cancer has now also become the most common cancer in women, which is a shift from earlier decades when cervical cancer was more common than breast cancer.

The aim of this report is to review the data on the burden of human papillomavirus (HPV) and HPV-related diseases in SSA countries, including: (Middle Africa) Angola, Cameroon, Central African Republic, Chad, Congo, Democratic Republic of Congo, Equatorial Guinea, Gabon, Säo Tomé and Principe; (Western Africa) Benin, Burkina Faso, Cape Verde, Côte 
d'Ivoire, Gambia, Ghana, Guinea, Guinea Bissau, Liberia, Mali, Mauritania, Niger, Nigeria, Saint Helena, Senegal, Sierra Leone, Togo; (Eastern Africa) Burundi, Comoros, Djibouti, Eritrea, Ethiopia, Kenya, Madagascar, Malawi, Mauritius, Mayotte, Mozambique, Réunion, Rwanda, Seychelles, Somalia, South Sudan, Sudan, Uganda, United Republic of Tanzania, Zambia, Zimbabwe; (Southern Africa) Botswana, Lesotho, Namibia, South Africa, Swaziland. Other important factors related to HPV and HPV-related diseases, such as the ongoing HIV epidemic and sociocultural determinants in the region are also reviewed.

\section{Burden of cervical cancer in sub-Saharan Africa}

\subsection{Cancer registration in the region: data sources and methods}

Geographical variations in cervical cancer incidence and mortality in SSA countries, information on age-specific incidence curves, survival, temporal trends, projections and an analysis on years of life lost (YLL) are presented in this section.

Country-specific GLOBOCAN 2008 estimations were used [2]. The country-specific cancer incidence and mortality rates for SSA were based on data reported by four national cancer registries (The Gambia, Namibia, Botswana, Swaziland) and some 40 local cancer registries. Although the national registries provided national data, they were still based on relatively low quality registration procedures and none were of sufficient quality to be included in the most recent volume of the IARC Cancer Incidence in Five Continents (CI5) [3]. The local registries generally covered major cities and were predominantly urban. Only two registries from Africa, (Kampala, Uganda and Harare, Zimbabwe) were included in CI5 vol. IX [3].

Fig. 1 shows the data sources used by GLOBOCAN to estimate cancer incidence in 2008 for SSA. No reliable cancer-specific mortality statistics are available in any SSA countries, and mortality in GLOBOCAN was estimated by combining corresponding estimates of cancer incidence with country-specific survival probabilities [2]. Incidence and mortality rates are presented as age-standardized rates (ASR), calculated using the weights of the "world standard" population [1-3].

The IARC CI5 was used for information on temporal trends, and GLOBOCAN was used for projections of ICC incidence from 2008 to 2030 . The projections assume that estimated rates in 2008 would be retained until 2030, with the forecasted population projections in 2030 applied to the age-specific rates in a given region or country. YLL were estimated by multiplying, for all world regions, the number of cancer-specific deaths at a given age by the standard life expectancy for age group. Mortality by age groups was derived from GLOBOCAN 2008. A standard female life expectancy scale, starting with 82.5 years at birth was used for all regions, i.e., the life expectancy for Japan, the highest observed in the world.

\subsection{Incidence and mortality}

SSA is the region with the highest incidence of ICC worldwide [1-3]. Although the region was home to an estimated $9 \%$ of the world female population >15 years of age in 2008, $14 \%$ of the world's incident ICC (75,141 cases each year) and $18 \%$ of the world's ICC deaths $(50,233)$ occurred in SSA. For an average woman in SSA, the cumulative ICC incidence and 
mortality risk (0-74 years) are 3.5\% and $2.7 \%$, respectively. The mortality risk is about $70 \%$ higher than in South-Central Asia (1.6\%), the region with the second highest cumulative mortality rates worldwide. The overall ICC age-standardized incidence and mortality rates (ASIR and ASMR) for SSA are 31.7 and 22.5 per 100,000 women, compared with 9.1 and 3.1, respectively, in more developed countries. Within the SSA region, estimated ASIR and ASMR are highest in Eastern and Western Africa with ASIR of 34.5 and 33.7 per 100,000 women, respectively, and ASMR of 25.3 and 24.0 per 100,000 women, respectively (Table 1 and Figs. 2 and 3). Not surprisingly, ICC is the most important cause for cancer death in women in Eastern, Western and Middle Africa and second most important cause after breast cancer in Southern Africa. The burden of ICC is highest in Guinea, Zambia, Tanzania, Malawi and Mozambique with ASIRs greater than 50/100,000 women (Supplementary Table 1).

In Fig. 4, age-specific ICC incidence rates by SSA sub-regions and less or more developed world regions are compared. In all SSA subregions, ASIRs rise by the age of 40-44 (36/100,000 and more) and reach a peak around the age of 55-65 years. This is similar but at a higher level, than what is seen in less developed world regions in general. Conversely, age-specific incidence is relatively lower in more developed countries, with a maximal rate $(20 / 100,000)$ at around 40 years of age that does not further increase. This is best explained by the effect of cervical cancer screening programs that stop the onset of cervical cancer in more developed countries, compared with most countries in the developing world, including SSA, which do not have national cervical cancer screening programs.

\subsection{Survival}

Cancer survival is related to the quality of early diagnosis, treatment and clinical follow-up care in any given setting. One study reliably assessed 5-year relative survival rates for women with ICC (5-year survival of women diagnosed with ICC, divided by the expected 5year survival derived from similar women from the general population) in three cancer registries in The Gambia, Uganda, and Zimbabwe for women registered with ICC between 1993 and 1997, and also in other countries from Asia and Central America [4]. Agestandardized relative survival (ASRS) after ICC diagnosis was the lowest in SSA, compared with other regions: $23 \%$ in The Gambia, $19 \%$ in Uganda, $44 \%$ in black populations and $61 \%$ in white populations in Zimbabwe. In comparison, ASRS exceeded 75\% in Hong Kong and South Korea, and $65 \%$ in Singapore. The three selected countries were the only ones in the region that fulfilled the inclusion criteria in terms of sustained reliable cancer data registration for this study. Therefore, it is quite likely that the survival rates in many SSA countries that were not included here would be even lower than those reported in this study. Striking differences in cancer survival between countries, or between distinct populations within a country, reflect the large inequality in accessible and available cancer health services for populations across the world. These poor survival rates emphasize the importance and urgent need for improvement of health services in SSA countries. 


\subsection{Temporal trends}

Ten-year trends for ASIR were compared between 1987-1989 and 1994-1996 in Bamako, Mali; between 1991-1993 and 1998-2002 in Kyadondo, Uganda; and between 1990-1992 and 1998-2002 in Harare, Zimbabwe (Table 2).

Trends in ASIR in SSA are not favorable. Increases were observed in Mali (23 to $36 / 100,000$ over time), and Uganda (41 to 46/100,000). However, a decrease was observed in Zimbabwe (65 to 48/100,000). The impact of HIV on trends in ICC incidence is not clear, as both Uganda and Zimbabwe had a highly elevated HIV prevalence among the general population in the nineties, and show opposite trends for cervical cancer over time. Parkin DM et al. [5] reported more details on cancer incidence trends in Kampala between 1991 and 2006. They noted a general increase in cancers linked to Western lifestyles, such as breast cancer (4.5\% increase annually), although cancers not linked to western lifestyles, such as stomach, liver, esophagus and cervical cancers, did not decrease over time. In fact, cervical cancer ASIR increased to 52/100,000 women for the period 2002-2006. This increase was unlikely to be related to the HIV epidemic, as most of the increase was seen in older (postmenopausal) women.

\subsection{Projections}

If the 2008 cancer incidence rates are applied to the projected demographic evolution between 2008 and 2030, namely increasing numbers and aging populations, an estimated 139,558 new cases of ICC will be diagnosed in 2030 in SSA. This is a $90 \%$ increase in most of the SSA sub-regions (Fig. 5), except in Southern Africa where the increase would be around 35\%. The relatively weaker increase in Southern Africa is a result of a lower projected population increase, mainly due to the rampant HIV epidemic in this sub-region [6]. An increase in the number of new cases of ICC in SSA could only be avoided if the ASIR were to decrease by $2 \%$ yearly, which would be hugely challenging, given the current lack of organized cervical cancer screening in the region. A larger increase in cervical cancer may also be recorded if an increasing number of HIV-positive women reach the age when cervical cancer starts being common or other risk factors for the disease (e.g., sexual behaviour) increase.

\subsection{Years of life lost}

ICC was estimated to be responsible for 1,474,208 YLL in women aged 15 years or more in the SSA region. It was the most important cause (20\%) of YLL due to cancer in women in the region, and represented 19\% of all YLL due to ICC worldwide (Fig. 6).

\section{Cervical HPV infection and type distribution in sub-Saharan Africa}

\subsection{Methods of the literature review}

The data presented on HPV prevalence in the cervix are based on literature updates of metaanalyses by Bruni L and colleagues on HPV in women with normal cytology [7] and by Li $\mathrm{N}$ and colleagues [8] on HPV in women with ICC. The literature search was updated to December 2011. Studies were eligible for inclusion if they reported on more than 100 women with normal cytology or 20 women with ICC, and used DNA polymerase chain 
reaction (PCR)-based assays or Hybrid Capture ${ }^{\circledR} 2$ (HC2), Qiagen Gaithersburg, Inc., MD, USA (previously Digene Corp.) techniques for HPV detection. A Medline search was performed using the keywords "HPV" and individual names of SSA countries. References cited in retrieved articles were also evaluated and included if appropriate. Studies were excluded if they reported on special populations (pregnant, HIV-positive, or women with a previous diagnosis of cervical lesion). For specific information on the HIV population and HPV please see Denny L et al,. Vaccine 2012 [9]. One study from Sudan including 94 women with normal cytology was also included because of the scarcity of data available from this area.

\subsection{HPV prevalence in women with normal cytology}

Twenty-three studies matched the above criteria and were included in this overview, presented in Table 3. The different subregions were fairly well represented, except for Middle Africa, with only one study from the Democratic Republic of Congo. HPV prevalence ranged between 3.2\% in Sudan [10] and 47.9\% in Guinea [11]. Although the reason for this is not very clear, this wide distribution could be explained by methodological differences between the studies, resulting in inclusion of study populations that show different risk for the presence of HPV, such as age or sexual behaviour. The most common HPV type detected in a majority (11/15) of studies that performed DNA typing was HPV16, with a prevalence range of $1.0-7.5 \%$.

In Western Africa, studies reported HPV prevalence for a total of 6,212 women with normal cytology (Table 3). The highest prevalence of HPV (any type) was found in Guinea, where 360/752 (47.9\%) women were HPV-positive using PCR technology [11]. Further, HPV16 was the most common type identified in women with normal cytology at $6.6 \%$, followed by HPV45 (4.7\%), $52(4.0 \%)$ and 18, 35 and 58 (3.2\% each). The lowest HPV prevalence was found in a Nigerian study of 1,075 women, of whom 113 (10.5\%) were high-risk (hr) HPV positive [12]. Of the three studies carried out in Nigeria, the range of HPV detection in women with normal cytology was $10.5-18.8 \%$ for the two studies that reported on hrHPV and $24.8 \%$ for the study that reported on a wider spectrum of HPV types [12-14].

The highest prevalences of HPV detected in women with normal cytology were found in Eastern Africa. HPV prevalences ranged from 3.2\% (3/94) in Sudan [10] to 41.4\% (84/203) in Mozambique [15].

In Southern Africa, data were only available from studies in Cape Town, South Africa. The range of HPV prevalence among women with normal cytology ranged from 15.5\% $(197 / 1,269)$ hrHPV [16], to 20.4\% (173/848) hrHPV [17].

The only study in Middle Africa from the Democratic Republic of Congo reported one of the lowest hrHPV positivities $(8.7 \%, 99 / 1,138)$ [18].

The meta-analysis by Bruni L et al. [7] reported on HPV type distribution among one million women with normal cytology worldwide, including 7,705 women from Africa. The HPV prevalences reported in this study were adjusted for geographical sub-region, women's age, study year, HPV testing method, proportion of high-risk and low-risk (LR) HPV tested, 
and clusters. Adjusted HPV prevalences among SSA women were estimated at 33.6\%, $19.6 \%$ and $17.4 \%$ in Eastern, Western and Southern Africa, respectively. By comparison, the overall estimate was $16.1 \%$ for Latin America and the Caribbean, $14.2 \%$ for Europe and $11.7 \%$ worldwide. Globally, $22.5 \%$ of HPV infections were attributed to HPV16. In SSA, HPV16 infections were found in lower percentages $(13.7 \%, 11.3 \%$ and $11.1 \%$ for Southern, Eastern and Western Africa, respectively), but HPV16 was still the most common type identified [7].

\subsection{HPV type distribution in invasive cervical cancers}

Twenty-four studies matched the above criteria and were included in the review (Table 4). No studies were identified from Middle Africa, but the other sub-regions were fairly well represented with 478 cases from Western Africa, 1,516 from Eastern Africa and 360 from Southern Africa. The most common HPV type detected in HPV-positive ICC among studies using broad-spectrum DNA PCR tests was HPV16, ranging from 38.5\% in Mali [19] to $81.8 \%$ in Tanzania [20]. In most of the studies, HPV18 and 45 were the second and third most frequent HPV types identified. The HPV16 and/or 18 relative contribution in ICC, when reported, ranged from 56.4\% [21] to 91.5\% [22]. In almost half of the studies in which information on HPV35 was reported, this type was the fourth in the ranking before HPV types 31 and 33 .

We mention here results of two large studies from the region among women with ICC that are not published to date, but were reported at international conferences. One recent multicenter study from Uganda reported on HPV type distribution in 379 HIV-negative and 107 HIV-positive women with ICC [23]. Eighty-four percent of cases (HIV-positive and HIV-negative) were HPV-positive, and the most common HPV types were HPV16 (49\%), HPV18 (23\%), HPV45 (13\%), and HPV35 (5\%). Another study by Schmidt J et al. [24] reported recently on HPV type distribution in women with ICC from South Africa, Ghana and Nigeria. Biopsy specimens were collected from 570 women from October 2007 to March 2010. A total of $93.7 \%$ of women were HPV-positive and $86.8 \%$ were infected with a single type. In those women infected with one HPV type, the most common types in women with squamous cell carcinoma ( $n=447$ ) were HPV16 (51.2\%), HPV18 (15\%), HPV35 (8.7\%), HPV45 (7.4\%). In women with adenocarcinoma $(n=27)$, HPV18 $(29.6 \%)$ was the most common, followed by HPV16 (22.2\%), HPV45 (18.5\%) and HPV35 (3.7\%).

In the recent meta-analysis by Guan P et al. [25], which included 2,402 HPV-positive cases of ICC from Africa, the most common HPV type was HPV16 (53.1\% of HPV-positive ICC), followed by HPV18 (19.8\%), HPV45 (11.0\%), and HPV35 (4.9\%). The same study calculated oncogenic potential of different types by comparing the prevalence of specific types in women positive for HPV over the disease spectrum. For instance, HPV35 was well represented in HPV-positive women with normal cytology (6.6\%) and with either low-grade (7.9\%) or high-grade (11.8\%) cervical cancer precursors [25]. However, HPV35 was poorly represented in invasive cancers $(4.9 \%)$ suggesting that its oncogenic potential is less than that of HPV 16 or 18 , which were relatively better represented in invasive cancer, compared with normal women or cancer precursors. The same was true for the types 31, 52 and 58, all very frequent in women with normal cytology, but less frequent in invasive cancer. The 
prevalence of HPV45 was higher in HPV-positive ICC in Africa (11.0\%), compared to other regions (3.0\% in Eastern Asia to 6.1\% in South/Central America), and was also increased in ICC, compared to HPV-positive women with normal cytology (5.9\%) in Africa [25].

Another study evaluated the results of HPV DNA testing on 10,575 ICC biopsies from 38 countries worldwide, of which 8,977 (85\%) were positive for HPV [26]. Of the 691 cases from Africa, 544 (79\%) were HPV-positive; of these, $443(81 \%)$ contained a single or undetermined HPV infection and 101 (19\%) had multiple types, which was the highest proportion for all regions (range $4 \%$ in North America to $11 \%$ in Oceania). This study confirmed that HPV16 is the most frequent type in ICC in Africa (48\% among HPV-positive results), followed by HPV18 (23\%), HPV45 (10\%), and HPV35 (5\%).

de Sanjosé S et al. [26] reported that multiple infections were most commonly found in SSA, however like in our review of the literature there was, in SSA, a wide regional variation of infection with multiple types from 2\% in Ethiopia [27] and South Africa [28] to $34 \%$ in Mozambique [29]. A fraction of this high number of multiple infections may be due to undiagnosed or unknown concurrent HIV infection. An increase in the proportion of multiple infections with HPV is well described in HIV-positive women, up to 10-fold compared with HIV-negative women with ICC (Denny L et al. Vaccine 2012 [9]).

\section{Other anogenital cancers in sub-Saharan Africa}

\subsection{Methods of the literature review}

Methods and data sources used in this section include: the IARC CI5 for retrieving the incidence of vulvar, vaginal, anal, and penile cancers in sub-Saharan African cancer registries [3]; HPV information for these anatomical sites was retrieved through a similar literature search as described in section 3 , however including men where appropriate, and without sample size limitations.

\subsection{Burden of vulvar, vaginal, anal and penile cancers}

All of these cancers are rare, as evidenced by their very small numbers and low incidence, reflected in cancer registry data from Uganda and Zimbabwe (Table 5). Penile cancer is also a rare tumour in developed countries but more common in South America and East Africa [3]. Although studies on the prevalence of HPV in vulvar, vaginal or anal cancers in SSA were not found, there is an increasing body of evidence from other parts of the globe strongly linking HPV DNA with cancers and pre-cancers of the anus, vulva, vagina, and penis [30-32].

\subsection{HPV prevalence in men}

Specimens from the genital and perianal regions of Kenyan men from the fishing industry revealed an HPV positivity rate of 57.6\% [33]. Table 6 shows the HPV type distribution and HPV tests performed in various studies in men in the SSA region. HPV analysis of specimens from similar anatomic regions (except perianal) of uncircumcised HIV-negative Kenyan men (recruited from various workplaces, community organizations and sexually transmitted infection [STI] clinics) revealed HPV presence in 51.1\% [34]. HIV-negative 
men recruited into male circumcision trials in Uganda showed varying presence of hrHPV infection depending on whether they were assessed at baseline (37.6\%) [35], uncircumcised and assessed at 1-year follow-up (36.3\%), or circumcised recruits and assessed at 1-year follow-up (21.5\%) [36]. Male recruits from a circumcision trial in South Africa showed similar trends in differences of HPV positivity between uncircumcised and circumcised males, with hrHPV prevalence of $23.2 \%$ and $14.0 \%$, respectively [37].Moreover, male circumcision has also been shown to result in reduction of HPV infections in the female partners of HIV-negative men [38].

\subsection{HPV prevalence in penile carcinoma}

The prevalence of HPV DNA in penile carcinoma ranges between $20 \%$ and $80 \%$, but varies depending on the methods utilized for detection, and geographical variability [39-42]. In small case studies of penile carcinoma from Uganda [43] and Kenya [44], HPV DNA was present in $64.7 \%$ and $68.2 \%$ of cases, respectively.

\section{Clinical burden of genital warts in sub-Saharan Africa}

\subsection{Methods of the literature review}

A Medline literature search was performed for studies reporting on prevalence and incidence of genital warts (GW) in SSA, published before January 2012. Keywords were used in the following search string: "Genital warts" OR "HPV" AND "Africa". References cited in retrieved articles were also evaluated and included if appropriate.

\subsection{Prevalence and incidence of genital warts in SSA}

GW have been recognised as a common sexually transmitted disease in SSA for many years. Latif AS [45] described 929 patients at a sexually transmitted disease clinic in Harare, Zimbabwe in 1980 and recorded prevalences of GW of $1.9 \%$ in men and $0.4 \%$ in women. Schmauz R and Owor R [46] studied GW in Uganda during the period 1964-1975 and provided clinical, pathological, and ecological evidence for a link between $\mathrm{GW}$ and cervical, vulvar, vaginal, and penile cancers.

As elsewhere, GW in Africa are most commonly associated with HPV6 or 11 [47]. Population-based data for GW incidence or prevalence in Africa are limited. Some data approximating this are available from recent large-scale phase 3 trials. MDP301 was a randomized controlled trial of $\mathrm{PRO} 2000$ vaginal microbicide gel in 9,385 women in South Africa, Tanzania, Uganda, and Zambia [48]. Women were selected as HIV-negative and non-pregnant at entry and had a mean age of 30 years. Over 8,079 women-years of followup, an incidence of GW of 0.4 per 100 women-years was recorded (Sheena McCormack, Imperial College, London, personal communication, December 2011), and this was in the presence of condom promotion and the potential anti-HPV activity of the polyanionic microbicide.

In SSA, the epidemiology of GW and genital HPV is inextricably interwoven with that of HIV infection. Low AJ and colleagues [49] performed a prospective study with median follow-up of 1.7 years in 765 high-risk women in Burkina Faso. At entry, mean age was 28 
years and HIV-1 prevalence was $35.6 \%$. GW prevalence at baseline was $1.6 \%$ among HIVnegative women and 7.0\% among HIV-positive women. During follow-up, GW incidence was 1.1 per 100 women-years among HIV-negative women, 7.4 per 100 women-years among HIV-positive women with a CD4+ lymphocyte nadir >200 cells, and 14.6 per 100 women-years among HIV-positive women with a CD4+ nadir <200 cells. Antiretroviral therapy was not protective against incident or persistent GW. Detection of HPV6 DNA and abnormal cervical cytology were strongly associated with incident GW.

The results of the Australian HPV vaccine program have shown that the most effective single strategy for significant control of GW disease burden in SSA would be populationbased implementation of quadrivalent HPV vaccination [50].

\section{Impact of the HIV epidemic on HPV-related disease}

For this section, a Medline literature search was performed on the topics of HPV and cervical cancer, HIV/AIDS, and studies from SSA region. A commentary on the underlying context along with the limited evidence to date on this topic from the SSA region is presented in this section (the interaction between HIV and HPV is described in greater detail elsewhere in this issue, Denny L et al. Vaccine, 2012 [9]).

The HIV/AIDS epidemic has negatively impacted health and development in many developing regions of the world, particularly in countries in SSA. HIV-infected individuals progressively develop opportunistic infections and AIDS-associated malignancies with deteriorating immune status, unless corrected by combination antiretroviral therapy (cART). HPV shares the sexual mode of transmission with HIV, although the former is more easily transmitted or acquired than the latter. Indeed, populations of both men and women who acquire HIV through sexual transmission have been shown to have a substantially higher prevalence of cervical/anal HPV infection (presumably also acquired sexually) than HIVuninfected individuals. Observational studies have shown that HIV-infected women have a higher risk of incidence and progression and lower likelihood of regression of cervical intraepithelial neoplasia (CIN) compared with HIV-uninfected women. Similar trends in risk are also observed for increasing prevalence of anal HPV infection and anal intraepithelial neoplasia (AIN) in HIV-infected men who have sex with men (MSM) [51] and HIV-infected women reporting history of anal sexual intercourse [52].

In addition, there is now some evidence that HPV infection may increase the probability of HIV acquisition. In a Kenyan male circumcision trial, it was found that the hazard ratio for incident HIV infection among men with HPV-positive glans/coronal sulcus specimens was 1.8 (95\% CI, 1.1-2.9), compared with men with HPV-negative glans/coronal sulcus specimens, after controlling for subsequent circumcision status, baseline herpes simplex virus type 2 serostatus, and sexual and sociodemographic risk factors [53]. Zimbabwean women with cervical low-risk HPV infection were also 1.7 times more likely to acquire HIV infection [54].

It has been shown that multiple HPV types are very common in precancerous lesions in HIV-infected populations [30,55]. HPV type 16 is the most common genotype, as in HIVuninfected populations, although the relative proportion of HPV16 compared to other 
carcinogenic HPV types is influenced by the degree of immunosuppression $[28,56,57]$. In addition to a wider variety and multiplicity of carcinogenic HPV types, HIV-infected individuals also have a high prevalence of non-carcinogenic HPV types, or HPV types with unknown carcinogenicity [58].While these types are almost always present along with concurrent HPV types in cervical/anal precancerous lesions, their etiologic significance is still unknown [58].

cART has only recently been implemented in SSA with variable coverage. In 2010, it was estimated by UNAIDS that $49 \%$ of people needing cART (CD4 350 cells $/ \mu \mathrm{L})$ in SSA had access to treatment [59]. In developing countries, before the widespread availability of cART, HIV-infected individuals often did not live long enough for precancerous lesions to progress to cancer $[60,61]$. If true that cART has a limited or no impact on reducing cervical/anal cancer incidence rates [62] (although this is controversial with conflicting reports in the literature), HIV-infected individuals who live longer on cART may be at increased risk of persistent HPV infection and precancerous CIN/AIN progressing to cervical/anal cancers respectively, unless effective screening and early treatment measures are put in place $[63,64]$. However, it is important to note that screening the anus for precancerous lesions and treating those detected has not yet been shown to prevent progression to anal cancer, as it has been shown with the detection and treatment of cervical cancer precursors. Recent observational evidence has also pointed to the importance of the level of adherence to cART as influencing the natural course (progression or regression) of cervical neoplastic disease [65].

\section{Sociocultural determinants of HPV-related disease}

For this section, a Medline literature search was performed on the topics of HPV, polygamy, armed conflict, violence, rape, and forced migration. Limited evidence for the SSA region was found and is presented below.

\subsection{Culture of sex and marriage in SSA and its role in HPV-related disease: Patterns of sexual behaviour and sexual networks (polygamy, multiple concurrent partnerships, core groups)}

Country-specific epidemiologic data for the SSA region are relatively sparse. However, the available data suggest that HPV infection is more common among women in SSA than among women in Asia, Europe, or the Americas, as described earlier in this chapter. Marked regional differences in HPV prevalence suggest that a complex array of social, cultural, and structural factors act to increase SSA women's risk of HPV infection and HPV-related disease.

Our English language literature search did not yield any qualitative or quantitative studies that specifically address sociocultural factors, such as concurrency, polygamy, or religious beliefs, associated with women's risk of HPV infection in SSA. However, several parallels may be drawn from the wide body of literature on HIV and other STIs. It is well established that risky sexual behaviours, including early sexual debut and having unsafe sex with multiple partners, increase women's risk of STIs, contributing substantially to the ongoing HIV epidemic in the region. Although concurrent sexual relationships, including 
polygamous marriage, may increase women's risk of STIs [66], this theory is not wholly supported by empirical findings and may apply differently to different STIs $[67,68]$. Therefore, health messaging and behavioural interventions that effectively reduce multiple partnerships, regardless of whether those partnerships overlap in time, continue to be an important yet elusive public health goal.

\subsection{Social destabilization, armed conflict, violence against women, and their impact on HPV-related disease}

Even in normal circumstances, accessibility of health services in SSA is hampered by the scarcity of subsidized care, and requires substantial cost contribution by individuals and families. In addition, vast areas of West Africa, the Great Lakes Region, and the Horn of Africa have recently experienced or are currently experiencing protracted armed conflict. Here, as in other parts of the world, war and unrest have had devastating effects on health and development [69]. Health systems, disease control programs, and reproductive health services in Africa's conflict-affected areas have been disrupted [70].War and unrest also have had profoundly destabilizing effects on human resources for health [71]. As a result, access to health services is severely limited for internally displaced persons and refugees in SSA.

More than limiting access to health services, war and unrest also commonly result in systematic and horrific acts of violence against women and girls [72]. Although there are innumerable examples and reports of escalating gender-based violence during armed conflicts—with rape increasingly used as a weapon of war across Africa [73] — there have been no epidemiologic studies examining whether women in conflict-affected areas face a higher burden of HPV infection and HPV-associated disease.

Nevertheless, it is abundantly evident that men, women, and children in conflict-affected areas worldwide face severely restricted access to essential health and social services. Future guidance and policy on humanitarian assistance should continue to promote minimum standards for health care, including expanded reproductive health services [74].

Development of equitable and sustainable national plans for comprehensive health services, including cancer prevention, screening, and treatment, should be a priority during postconflict reconstruction of health systems.

\section{Conclusion}

HPV-associated diseases, particularly cervical cancer, are major causes of morbidity and mortality in SSA. Cervical cancer incidence rates in SSA are the highest in the world and the disease is the most common cause of cancer death among women in the region. It is expected that due to lack of access to appropriate prevention services and the concomitant HIV/AIDS epidemic, cervical cancer incidence and mortality rates in SSA will rise over the next 20 years. HPV16 and HPV18 are the most common genotypes in cervical cancer in SSA, although other carcinogenic HPV types are also relatively more frequent compared to other world regions. Even in women with normal cervical cytology in SSA, at least one in five are infected with carcinogenic HPV genotypes. Data on other HPV-related anogenital cancers including those of the vulva, vagina, anus, penis and head and neck cancers are 
limited. GW are common and associated with HPV types 6 and 11. HIV infection increases incidence and prevalence of all HPV-associated diseases. Sociocultural determinants of HPV-related disease, as well as the impact of forces that result in social destabilization, demand further study. Strategies to reduce the excessive burden of HPV-related diseases in SSA include age-appropriate prophylactic HPV vaccination, cervical cancer prevention services for women of the reproductive ages, control of HIV/AIDS, and health promotion strategies such as sexual education and lifestyle modification.

\section{Supplementary Material}

Refer to Web version on PubMed Central for supplementary material.

\section{Acknowledgments}

This work was supported by the Bill \& Melinda Gates Foundation (BMGF), USA (grant number 35537). Laia Alemany's work was partially supported by public grants from the Instituto de Salud Carlos III (Spanish Government) (grants RCESP C03/09, RTICESP C03/10, RTIC RD06/0020/0095, RD12/0036/0056 and CIBERESP) and from the Agència de Gestió d'Ajuts Universitaris i de Recerca - Generalitat de Catalunya (Catalonian Government) (grants AGAUR 2005SGR00695 and AGAUR 2009SGR126).

LA: Institutional support: HPV vaccine trials and epidemiological studies sponsored by GlaxoSmithKline, Merck and Sanofi Pasteur MSD. Personal support: Travel grants to conferences occasionally granted by Merck and Sanofi Pasteur MSD. LD: Has received honoraria for appearing on various speaker fora from GlaxoSmithKline and Merck/and Co. and sponsorship for research studies.

\section{References}

1. Jemal A, Bray F, Forman D, O`Brien M, Ferlay J, Center M, et al. Cancer burden in Africa and opportunities for prevention. Cancer. 2012 Jan 17. [Epub ahead of print].

2. Ferlay, J.; Shin, HR.; Bray, F.; Forman, D.; Mathers, C.; Parkin, DM. GLOBOCAN 2008, Cancer Incidence and Mortality Worldwide: IARC CancerBase No. 10. Lyon, France: International Agency for Research on Cancer; 2010. Available at: http://globocan.iarc.fr [last accessed April 2013]

3. Curado, MP.; Edwards, B.; Shin, HR.; Storm, H.; Ferlay, J.; Heanue, M., et al. Cancer Incidence in Five Continents, Vol. IX. IARC Scientific Publication No. 160. [IX]. Lyon: IARC; 2007.

4. Sankaranarayanan R, Swaminathan R, Brenner H, Chen K, Chia KS, Chen JG, et al. Cancer survival in Africa, Asia, and Central America: a population-based study. Lancet Oncol. 2010; 11:165-173. [PubMed: 20005175]

5. Parkin DM, Nambooze S, Wabwire-Mangen F, Wabinga HR. Changing cancer incidence in Kampala, Uganda, 1991-2006. Int J Cancer. 2010; 126:1187-1195. [PubMed: 19688826]

6. United Nations Department of Economic and Social Affairs, Population Division. World Population Prospects: The 2008 Revision, Highlights. [2009] Report No;1; ESA/P/WP.210.

7. Bruni L, Diaz M, Castellsagué X, Ferrer E, Bosch FX, de Sanjosé S. Cervical human papillomavirus prevalence in 5 continents: meta-analysis of 1 million women with normal cytological findings. J Infect Dis. 2010; 202:1789-1799. [PubMed: 21067372]

8. Li N, Franceschi S, Howell-Jones R, Snijders PJ, Clifford GM. Human papillomavirus type distribution in 30,848 invasive cervical cancers worldwide: Variation by geographical region, histological type and year of publication. Int J Cancer. 2011; 128:927-935. [PubMed: 20473886]

9. Denny L, Franceschi S, de Sanjosé S, Heard I, Moscicki AB, Palefsky J. Human papillomavirus, human immune deficiency virus and immunosuppression. Vaccine. 2012; 30(Suppl 5):F168-F174. [PubMed: 23199960]

10. Salih MM, Safi ME, Hart K, Tobi K, Adam I. Genotypes of human papilloma virus in Sudanese women with cervical pathology. Infect Agent Cancer. 2010; 5:26. [PubMed: 21192803] 
11. Keita N, Clifford GM, Koulibaly M, Douno K, Kabba I, Haba M, et al. HPV infection in women with and without cervical cancer in Conakry, Guinea. Br J Cancer. 2009; 101:202-208. [PubMed: 19536089]

12. Gage JC, Ajenifuja KO, Wentzensen NA, Adepiti AC, Eklund C, Reilly M, et al. The age-specific prevalence of human papillomavirus and risk of cytologic abnormalities in rural Nigeria: Implications for screen-and-treat strategies. Int J Cancer. 2012; 130:2111-2117. [PubMed: 21630264]

13. Thomas JO, Herrero R, Omigbodun AA, Ojemakinde K, Ajayi IO, Fawole A, et al. Prevalence of papillomavirus infection in women in Ibadan, Nigeria: a population-based study. Br J Cancer. 2004; 90:638-645. [PubMed: 14760378]

14. Schnatz PF, Markelova NV, Holmes D, Mandavilli SR, O‘Sullivan DM. The prevalence of cervical HPV and cytological abnormalities in association with reproductive factors of rural Nigerian women. J Womens Health (Larchmt). 2008; 17:279-285. [PubMed: 18321179]

15. Naucler P, Mabota da Costa F, da Costa JL, Ljungberg O, Bugalho A, Dillner J. Human papillomavirus type-specific risk of cervical cancer in a population with high human immunodeficiency virus prevalence: case-control study. J Gen Virol. 2011; 92(Pt 12):2784-2791. [PubMed: 21900420]

16. Wright TC Jr, Denny L, Kuhn L, Pollack A, Lorincz A. HPV DNA testing of self-collected vaginal samples compared with cytologic screening to detect cervical cancer. JAMA. 2000; 283:81-86. [PubMed: 10632284]

17. Allan B, Marais DJ, Hoffman M, Shapiro S, Williamson AL. Cervical human papillomavirus (HPV) infection in South African women: implications for HPV screening and vaccine strategies. J Clin Microbiol. 2008; 46:740-742. [PubMed: 17977997]

18. Sangwa-Lugoma G, Ramanakumar AV, Mahmud S, Liaras J, Kayembe PK, Tozin RR, et al. Prevalence and determinants of high-risk human papillomavirus infection in women from a subSaharan African community. Sex Transm Dis. 2011; 38:308-315. [PubMed: 21150817]

19. Bosch FX, Manos MM, Muñoz N, Sherman M, Jansen AM, Peto J, et al. Prevalence of human papillomavirus in cervical cancer: a worldwide perspective, International biological study on cervical cancer (IBSCC) Study Group. J Natl Cancer Inst. 1995; 87:796-802. [PubMed: 7791229]

20. Vidal AC, Murphy SK, Hernandez BY, Vasquez B, Bartlett JA, Oneko O, et al. Distribution of HPV genotypes in cervical intraepithelial lesions and cervical cancer in Tanzanian women. Infect Agent Cancer. 2011; 6:20. [PubMed: 22081870]

21. Williamson AL, Brink NS, Dehaeck CM, Ovens S, Soeters R, Rybicki EP. Typing of human papillomaviruses in cervical carcinoma biopsies from Cape Town. J Med Virol. 1994; 43:231237. [PubMed: 7931183]

22. Kay P, Soeters R, Nevin J, Denny L, Dehaeck CM, Williamson AL. High prevalence of HPV 16 in South African women with cancer of the cervix and cervical intraepithelial neoplasia. J Med Virol. 2003; 71:265-273. [PubMed: 12938202]

23. Muwogue, C.; Musana, O.; Othieno, E.; GGayi, A.; Levin, J.; Hugues, P., et al. The spectrum of HPV genotypes in cervical cancer in Uganda [Poster]. Presented at the 26th International Papillomavirus Conference and Clinical Workshop; 03-08 July 2010; Montreal, Canada. Presentation P-620.

24. Schmidt, J.; Adewole, I.; Anorlu, R.; Moodley, M.; Smith, T.; Wiredu, E., et al. HPV type distribution in invasive cervical cancer in Sub-Saharan Africa [Abstract]. Presented at the 27th International Papillomavirus Conference and Clinical Workshop; 17-22 September 2011; Berlin Germany. Presentation P-32-39.

25. Guan P, Howell-Jones R, Li N, Bruni L, de Sanjosé S, Franceschi S, et al. Human papillomavirus (HPV) types in 115,789 HPV-positive women: A meta-analysis from cervical infection to cancer. Int J Cancer. 2012; 131:2349-2359. [PubMed: 22323075]

26. de Sanjosé S, Quint WG, Alemany L, Geraets DT, Klaustermeier JE, Lloveras B, et al. Human papillomavirus genotype attribution in invasive cervical cancer: a retrospective cross-sectional worldwide study. Lancet Oncol. 2010; 11:1048-1056. [PubMed: 20952254] 
27. Bekele A, Baay M, Mekonnen Z, Suleman S, Chatterjee S. Human papillomavirus type distribution among women with cervical pathology - a study over 4 years at Jimma Hospital, southwest Ethiopia. Trop Med Int Health. 2010; 15:890-893. [PubMed: 20545913]

28. DeVuyst H, Ndirangu G, Moodley M, Tenet V, Estambale B, Meijer CJ, et al. Prevalence of human papillomavirus in women with invasive cervical carcinoma by HIV status in Kenya and South Africa. Int J Cancer. 2012; 131:949-955. [PubMed: 21960453]

29. Naucler P, Da Costa FM, Ljungberg O, Bugalho A, Dillner J. Human papillomavirus genotypes in cervical cancers in Mozambique. J Gen Virol. 2004; 85(Pt 8):2189-2190. [PubMed: 15269357]

30. De Vuyst H, Clifford GM, Nascimento MC, Madeleine MM, Franceschi S. Prevalence and type distribution of human papillomavirus in carcinoma and intraepithelial neoplasia of the vulva, vagina and anus: a meta-analysis. Int J Cancer. 2009; 124:1626-1636. [PubMed: 19115209]

31. Miralles-Guri C, Bruni L, Cubilla AL, Castellsagué X, Bosch FX, de Sanjosé S. Human papillomavirus prevalence and type distribution in penile carcinoma. J Clin Pathol. 2009; 62:870 878. [PubMed: 19706632]

32. Insinga RP, Liaw KL, Johnson LG, Madeleine MM. A systematic review of the prevalence and attribution of human papillomavirus types among cervical, vaginal, and vulvar precancers and cancers in the United States. Cancer Epidemiol Biomarkers Prev. 2008; 17:1611-1622. [PubMed: 18628412]

33. Ng'ayo MO, Bukusi E, Rowhani-Rahbar A, Koutsky LA, Feng Q, Kwena ZA, et al. Epidemiology of human papillomavirus infection among fishermen along Lake Victoria Shore in the Kisumu District, Kenya. Sex Transm Infect. 2008; 84:62-66. [PubMed: 17991686]

34. Smith JS, Backes DM, Hudgens MG, Bailey RC, Veronesi G, Bogaarts M, et al. Prevalence and risk factors of human papillomavirus infection by penile site in uncircumcised Kenyan men. Int J Cancer. 2010; 126:572-577. [PubMed: 19626601]

35. Tobian AA, Serwadda D, Quinn TC, Kigozi G, Gravitt PE, Laeyendecker O, et al. Male circumcision for the prevention of HSV-2 and HPV infections and syphilis. N Engl J Med. 2009; 360:1298-1309. [PubMed: 19321868]

36. Tobian AA, Kong X, Gravitt PE, Eaton KP, Kigozi G, Serwadda D, et al. Male circumcision and anatomic sites of penile high-risk human papillomavirus in Rakai, Uganda. Int J Cancer. 2011; 129:2970-2975. [PubMed: 21462185]

37. Auvert B, Sobngwi-Tambekou J, Cutler E, Nieuwoudt M, Lissouba P, Puren A, et al. Effect of male circumcision on the prevalence of high-risk human papillomavirus in young men: results of a randomized controlled trial conducted in Orange Farm, South Africa. J Infect Dis. 2009; 199:1419. [PubMed: 19086814]

38. Wawer MJ, Tobian AA, Kigozi G, Kong X, Gravitt PE, Serwadda D, et al. Effect of circumcision of HIV-negative men on transmission of human papillomavirus to HIV-negative women: a randomised trial in Rakai, Uganda. Lancet. 2011; 377(9761):209-218. [PubMed: 21216000]

39. Rubin MA, Kleter B, Zhou M, Ayala G, Cubilla AL, Quint WG, et al. Detection and typing of human papillomavirus DNA in penile carcinoma: evidence for multiple independent pathways of penile carcinogenesis. Am J Pathol. 2001; 159:1211-1218. [PubMed: 11583947]

40. Daling JR, Madeleine MM, Johnson LG, Schwartz SM, Shera KA, Wurscher MA, et al. Penile cancer: importance of circumcision, human papillomavirus and smoking in in situ and invasive disease. Int J Cancer. 2005; 116:606-616. [PubMed: 15825185]

41. Picconi MA, Eijan AM, Distefano AL, Pueyo S, Alonio LV, Gorostidi S, et al. Human papillomavirus (HPV) DNA in penile carcinomas in Argentina: analysis of primary tumors and lymph nodes. J Med Virol. 2000; 61:65-69. [PubMed: 10745234]

42. Senba M, Kumatori A, Fujita S, Jutavijittum P, Yousukh A, Moriuchi T, et al. The prevalence of human papillomavirus genotypes in penile cancers from northern Thailand. J Med Virol. 2006; 78:1341-1346. [PubMed: 16927292]

43. Tornesello ML, Duraturo ML, Guida V, Losito S, Botti G, Pilotti S, et al. Analysis of TP53 codon 72 polymorphism in HPV-positive and HPV-negative penile carcinoma. Cancer Lett. 2008; 269:159-164. [PubMed: 18513854] 
44. Senba M, Buziba N, Mori N, Wada A, Irie S, Toriyama K. Detection of Human papillomavirus and cellular regulators p16INK4a, p53, and NF-kappaB in penile cancer cases in Kenya. Acta Virol. 2009; 53:43-48. [PubMed: 19301950]

45. Latif AS. Sexually, transmitted disease in clinic patients in Salisbury, Zimbabwe. Br J Vener Dis. 1981; 57:181-183. [PubMed: 6894561]

46. Schmauz R, Owor R. Epidemiological aspects of cervical cancer in tropical Africa. IARC Sci Publ. 1984; (63):413-431. [PubMed: 6399280]

47. Firnhaber C, Sello M, Maskew M, Williams S, Schulze D, Williamson AL, et al. Human papillomavirus types in HIV seropositive men with penile warts in Johannesburg, South Africa. Int J STD AIDS. 2011; 22:107-109. [PubMed: 21427434]

48. McCormack S, Ramjee G, Kamali A, Rees H, Crook AM, Gafos M, et al. PRO2000 vaginal gel for prevention of HIV-1 infection (Microbicides Development Programme 301): a phase 3, randomised, double-blind, parallel-group trial. Lancet. 2010; 376(9749):1329-1337. [PubMed: 20851460]

49. Low AJ, Clayton T, Konate I, Nagot N, Ouedraogo A, Huet C, et al. Genital warts and infection with human immunodeficiency virus in high-risk women in Burkina Faso: a longitudinal study. BMC Infect Dis. 2011; 11:20. [PubMed: 21251265]

50. Read TR, Hocking JS, Chen MY, Donovan B, Bradshaw CS, Fairley CK. The near disappearance of genital warts in young women 4 years after commencing a national human papillomavirus (HPV) vaccination programme. Sex Transm Infect. 2011; 87:544-547. [PubMed: 21970896]

51. Guimaraes MD, Grinsztejn B, Melo VH, Rocha GM, Campos LN, Pilotto JH, et al. Anal HPV prevalence and associated factors among HIV-seropositive men under antiretroviral treatment in Brazil. J Acquir Immune Defic Syndr. 2011; 57(Suppl 3):S217-S224. [PubMed: 21857322]

52. Kojic EM, Cu-Uvin S, Conley L, Bush T, Onyekwuluje J, Swan DC, et al. Human papillomavirus infection and cytologic abnormalities of the anus and cervix among HIV-infected women in the study to understand the natural history of HIV/AIDS in the era of effective therapy (the SUN study). Sex Transm Dis. 2011; 38:253-259. [PubMed: 20966828]

53. Smith JS, Moses S, Hudgens MG, Parker CB, Agot K, Maclean I, et al. Increased risk of HIV acquisition among Kenyan men with human papillomavirus infection. J Infect Dis. 2010; 201:1677-1685. [PubMed: 20415595]

54. Smith-McCune KK, Shiboski S, Chirenje MZ, Magure T, Tuveson J, Ma Y, et al. Type-specific cervico-vaginal human papillomavirus infection increases risk of HIV acquisition independent of other sexually transmitted infections. PLoS One. 2010; 5:e10094. [PubMed: 20386706]

55. Clifford GM, Goncalves MA, Franceschi S. Human papillomavirus types among women infected with HIV: a meta-analysis. AIDS. 2006; 20:2337-2344. [PubMed: 17117020]

56. Sahasrabuddhe VV, Mwanahamuntu MH, Vermund SH, Huh WK, Lyon MD, Stringer JS, et al. Prevalence and distribution of HPV genotypes among HIV-infected women in Zambia. Br J Cancer. 2007; 96:1480-1483. [PubMed: 17437020]

57. Strickler HD, Palefsky JM, Burk RD. HPV types present in invasive cervical cancers of HIVseropositive women. Int J Cancer. 2008; 123:1224-1225. [PubMed: 18537158]

58. Broker TR, Jin G, Croom-Rivers A, Bragg SM, Richardson M, Chow LT, et al. Viral latency-the papillomavirus model. Dev Biol (Basel). 2001; 106:443-451. [PubMed: 11761260]

59. WHO. Global HIV/AIDS response; Progress report 2011. Available at: http:// www.who.int/hiv/pub/progress_report2011/regional_facts/en/index.html

60. Franceschi S, Jaffe H. Cervical cancer screening of women living with HIV infection: amust in the era of antiretroviral therapy. Clin Infect Dis. 2007; 45:510-513. [PubMed: 17638204]

61. Grulich AE, Jin F, Conway EL, Stein AN, Hocking J. Cancers attributable to human papillomavirus infection. Sex Health. 2010; 7:244-252. [PubMed: 20719211]

62. Bratcher LF, Sahasrabuddhe VV. The impact of antiretroviral therapy on HPV and cervical intraepithelial neoplasia: current evidence and directions for future research. Infect Agent Cancer. 2010; 5:8. [PubMed: 20462441]

63. Czoski-Murray C, Karnon J, Jones R, Smith K, Kinghorn G. Cost-effectiveness of screening highrisk HIV-positive men who have sex with men (MSM) and HIV-positive women for anal cancer. Health Technol Assess. 2010; 14:iii-x. 1. [PubMed: 21083999] 
64. Palefsky JM. Human papillomavirus-related disease in men: not just a women's issue. J Adolesc Health. 2010; 46(4 Suppl):S12-S19. [PubMed: 20307839]

65. Minkoff H, Zhong Y, Burk RD, Palefsky JM, Xue X, Watts DH, et al. Influence of adherent and effective antiretroviral therapy use on human papillomavirus infection and squamous intraepithelial lesions in human immunodeficiency virus-positive women. J Infect Dis. 2010; 201:681-690. [PubMed: 20105077]

66. Mah TL, Halperin DT. Concurrent sexual partnerships and the HIV epidemics in Africa: evidence to move forward. AIDS Behav. 2010; 14:11-16. [PubMed: 18648926]

67. Lurie MN, Rosenthal S. Concurrent partnerships as a driver of the HIV Epidemic in sub-Saharan Africa. The evidence is limited AIDS Behav. 2010; 14:17-24.

68. Tanser F, Barnighausen T, Hund L, Garnett GP, McGrath N, Newell ML. Effect of concurrent sexual partnerships on rate of new HIV infections in a high-prevalence, rural South African population: a cohort study. Lancet. 2011; 378(9787):247-255. [PubMed: 21763937]

69. UN High Commissioner for Refugees. Trends in Displacement, Protection and Solutions: Ten Years of Statistics. 2011 Available at: http://www.unhcr.org.

70. Rubenstein LS. Post-conflict health reconstruction: search for a policy. Disasters. 2011; 35:680700. [PubMed: 21913931]

71. Pavignani E. Human resources for health through conflict and recovery: lessons from African countries. Disasters. 2011; 35:661-679. [PubMed: 21913930]

72. Cottingham J, Garcia-Moreno C, Reis C. Sexual and reproductive health in conflict areas: the imperative to address violence against women. BJOG. 2008; 115:301-303. [PubMed: 18190365]

73. Kivlahan C, Ewigman N. Rape as a weapon of war in modern conflicts. BMJ. 2010; 340:c3270. [PubMed: 20576708]

74. Spiegel PB, Checchi F, Colombo S, Paik E. Health-care needs of people affected by conflict: future trends and changing frameworks. Lancet. 2010; 375(9711):341-345. [PubMed: 20109961]

75. Piras F, Piga M, De MA, Zannou AR, Minerba L, Perra MT, et al. Prevalence of human papillomavirus infection in women in Benin, West Africa. Virol J. 2011; 8:514. [PubMed: 22074103]

76. La Ruche G, You B, Mensah-Ado I, Bergeron C, Montcho C, Ramon R, et al. Human papillomavirus and human immunodeficiency virus infections: relation with cervical dysplasianeoplasia in African women. Int J Cancer. 1998; 76:480-486. [PubMed: 9590121]

77. Adjorlolo-Johnson G, Unger ER, Boni-Ouattara E, Toure-Coulibaly K, Maurice C, Vernon SD, et al. Assessing the relationship between HIV infection and cervical cancer in Cote d'Ivoire: a casecontrol study. BMC Infect Dis. 2010; 10:242. [PubMed: 20716343]

78. Wall SR, Scherf CF, Morison L, Hart KW, West B, Ekpo G, et al. Cervical human papillomavirus infection and squamous intraepithelial lesions in rural Gambia, West Africa: viral sequence analysis and epidemiology. Br J Cancer. 2005; 93:1068-1076. [PubMed: 16106268]

79. Tracy JK, Traore CB, Bakarou K, Dembele R, Coulibaly RC, Sow SO. Risk factors for high-risk human papillomavirus infection in unscreened Malian women. Trop Med Int Health. 2011; 16:1432-1438. [PubMed: 21749583]

80. Astori G, Beltrame A, Pipan C, Raphenon G, Botta GA. PCR-RFLP-detected human papilloma virus infection in a group of senegalese women attending an STD clinic and identification of a new HPV-68 subtype. Intervirology. 1999; 42:221-227. [PubMed: 10567840]

81. Xi LF, Toure P, Critchlow CW, Hawes SE, Dembele B, Sow PS, et al. Prevalence of specific types of human papillomavirus and cervical squamous intraepithelial lesions in consecutive, previously unscreened, West-African women over 35 years of age. Int J Cancer. 2003; 103:803-809. [PubMed: 12516102]

82. De Vuyst H, Steyaert S, Van Renterghem L, Claeys P, Muchiri L, Sitati S, et al. Distribution of human papillomavirus in a family planning population in Nairobi, Kenya. Sex Transm Dis. 2003; 30:137-142. [PubMed: 12567172]

83. De Vuyst H, Parisi MR, Karani A, Mandaliya K, Muchiri L, Vaccarella S, et al. The prevalence of human papillomavirus infection in Mombasa, Kenya. Cancer Causes Control. 2010; 21:23092313. [PubMed: 20938733] 
84. Castellsagué X, Menendez C, Loscertales MP, Kornegay JR, dos Santos F, Gomez-Olive FX, et al. Human papillomavirus genotypes in rural Mozambique. Lancet. 2001; 358(9291):1429-1430. [PubMed: 11705494]

85. Odida M, Sandin S, Mirembe F, Kleter B, Quint W, Weiderpass E. HPV types, HIV and invasive cervical carcinoma risk in Kampala, Uganda: a case-control study. Infect Agent Cancer. 2011; 6:8. [PubMed: 21702999]

86. Womack SD, Chirenje ZM, Gaffikin L, Blumenthal PD, McGrath JA, Chipato T, et al. HPV-based cervical cancer screening in a population at high risk for HIV infection. Int J Cancer. 2000; 85:206-210. [PubMed: 10629079]

87. Jones HE, Allan BR, van de Wijgert JH, Altini L, Taylor SM, de Kock A, et al. Agreement between self- and clinician-collected specimen results for detection and typing of high-risk human papillomavirus in specimens from women in Gugulethu, South Africa. J Clin Microbiol. 2007; 45:1679-1683. [PubMed: 17409209]

88. Bayo S, Bosch FX, de Sanjosé S, Muñoz N, Combita AL, Coursaget P, et al. Risk factors of invasive cervical cancer in Mali. Int J Epidemiol. 2002; 31:202-209. [PubMed: 11914322]

89. Okolo C, Franceschi S, Adewole I, Thomas JO, Follen M, Snijders PJ, et al. Human papillomavirus infection in women with and without cervical cancer in Ibadan, Nigeria. Infect Agent Cancer. 2010; 5:24. [PubMed: 21129194]

90. Lin P, Koutsky LA, Critchlow CW, Apple RJ, Hawes SE, Hughes JP, et al. HLA class II DR-DQ and increased risk of cervical cancer among Senegalese women. Cancer Epidemiol Biomarkers Prev. 2001; 10:1037-1045. [PubMed: 11588129]

91. Fanta BE. The distribution of Human Papilloma Virus infection in women with cervical histological abnormalities from an area with high incidence of cervical cancer. Ethiop Med J. 2005; 43:151-158. [PubMed: 16370546]

92. De Vuyst H, Gichangi P, Estambale B, Njuguna E, Franceschi S, Temmerman M. Human papillomavirus types in women with invasive cervical carcinoma by HIV status in Kenya. Int J Cancer. 2008; 122:244-246. [PubMed: 17764116]

93. Castellsagué X, Klaustermeier J, Carrilho C, Albero G, Sacarlal J, Quint W, et al. Vaccine-related HPV genotypes in women with and without cervical cancer in Mozambique: burden and potential for prevention. Int J Cancer. 2008; 122:1901-1904. [PubMed: 18076064]

94. ter Meulen J, Eberhardt HC, Luande J, Mgaya HN, Chang-Claude J, Mtiro H, et al. Human papillomavirus (HPV) infection, HIV infection and cervical cancer in Tanzania, east Africa. Int J Cancer. 1992; 51:515-521. [PubMed: 1318265]

95. Odida M, de Sanjosé S, Quint W, Bosch XF, Klaustermeier J, Weiderpass E. Human Papillomavirus type distribution in invasive cervical cancer in Uganda. BMC Infect Dis. 2008; 8:85. [PubMed: 18577214]

96. Stanczuk GA, Kay P, Sibanda E, Allan B, Chirara M, Tswana SA, et al. Typing of human papillomavirus in Zimbabwean patients with invasive cancer of the uterine cervix. Acta Obstet Gynecol Scand. 2003; 82:762-766. [PubMed: 12848649]

97. Pegoraro RJ, Rom L, Lanning PA, Moodley M, Naiker S, Moodley J. P53 codon 72 polymorphism and human papillomavirus type in relation to cervical cancer in South African women. Int $\mathrm{J}$ Gynecol Cancer. 2002; 12:383-388. [PubMed: 12144687] 


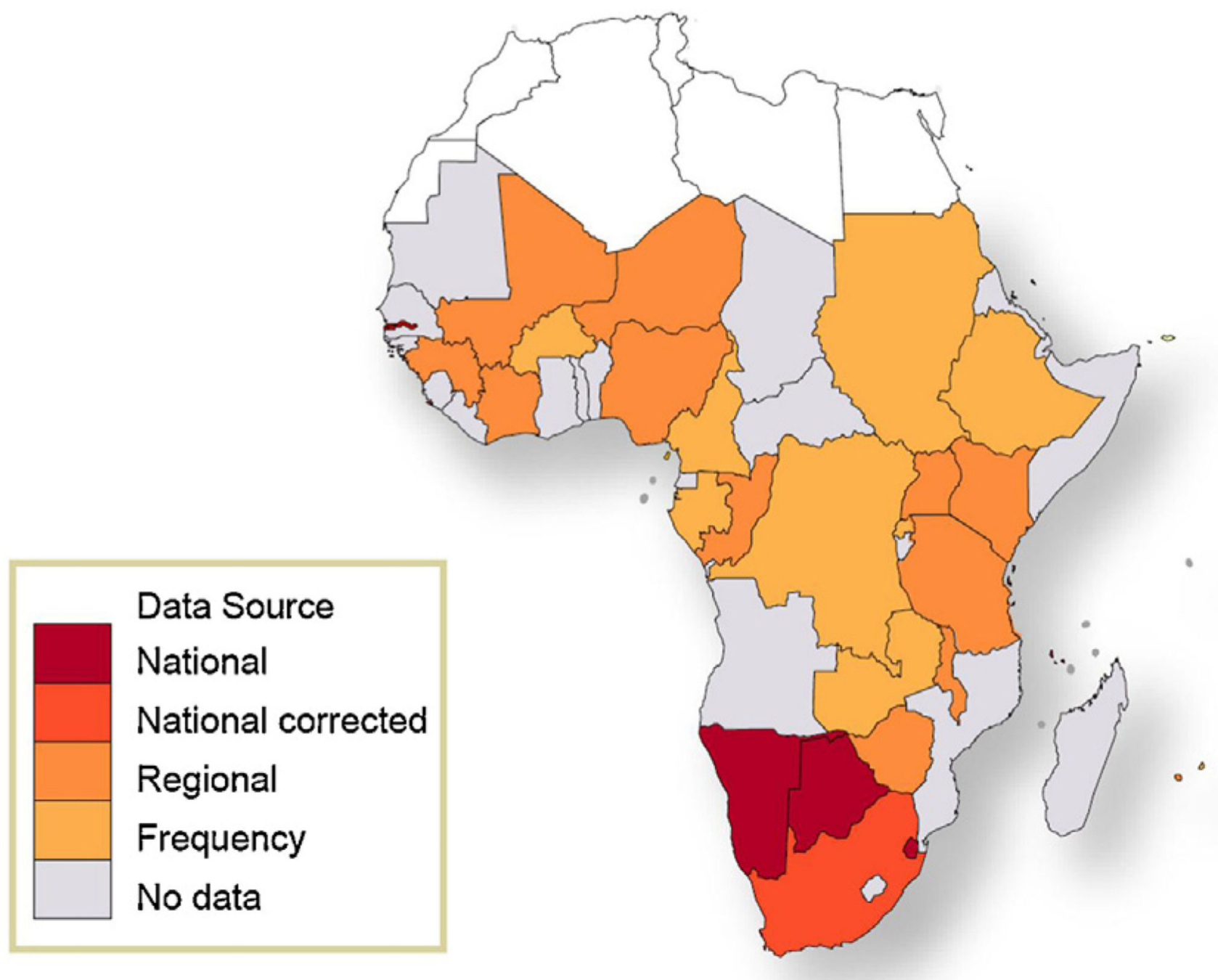

Fig. 1.

Methods of estimation for GLOBOCAN 2008 cancer incidence data for the sub-Saharan Africa region. Adapted from Jemal A et al. [1]. 


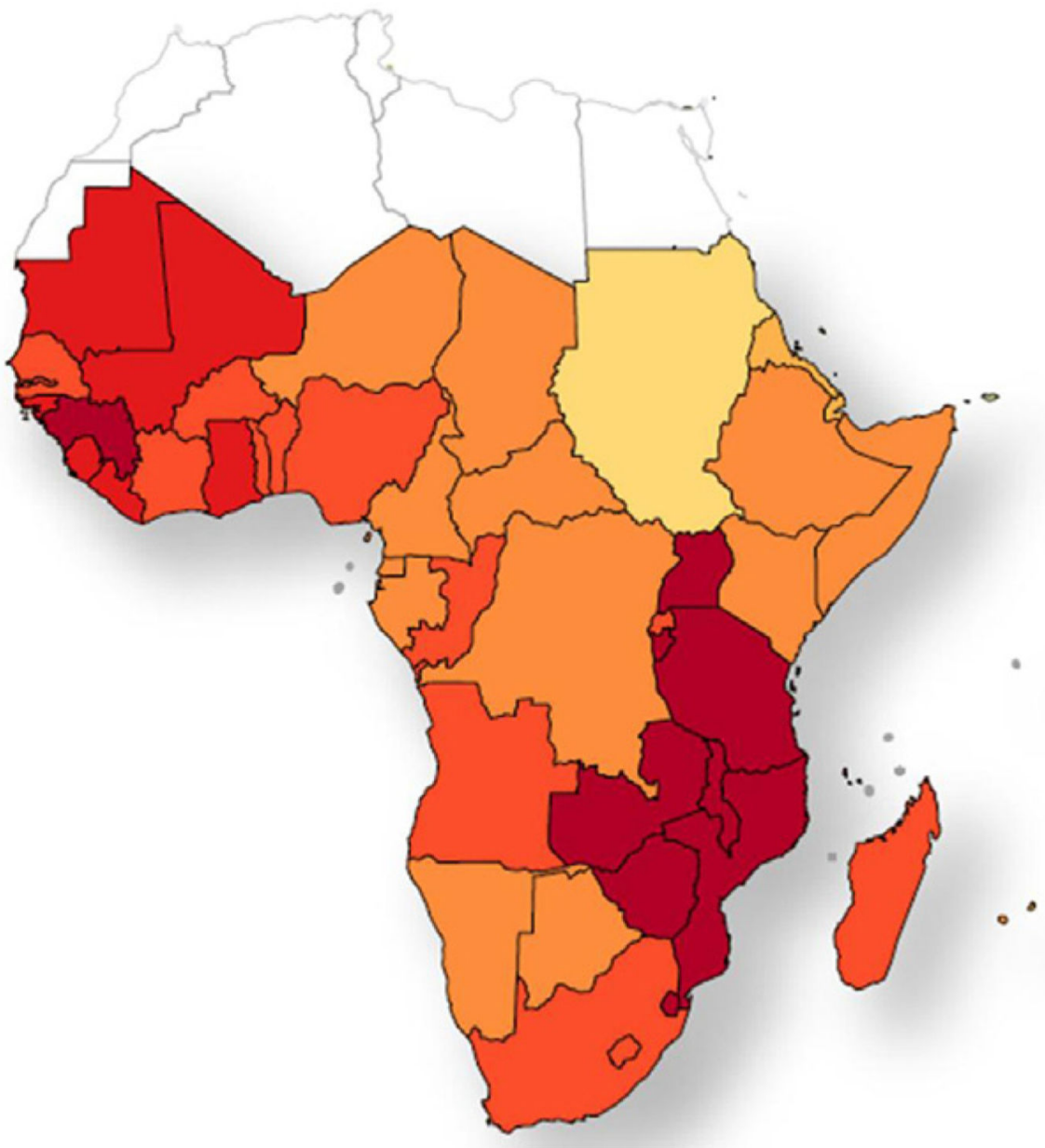

Fig. 2.

Age-standardized incidence rates of cervical cancer in sub-Saharan Africa region. Adapted from GLOBOCAN 2008 [2]. ASR: Age-standardized incidence rate, per 100,000 women and year (all ages). 


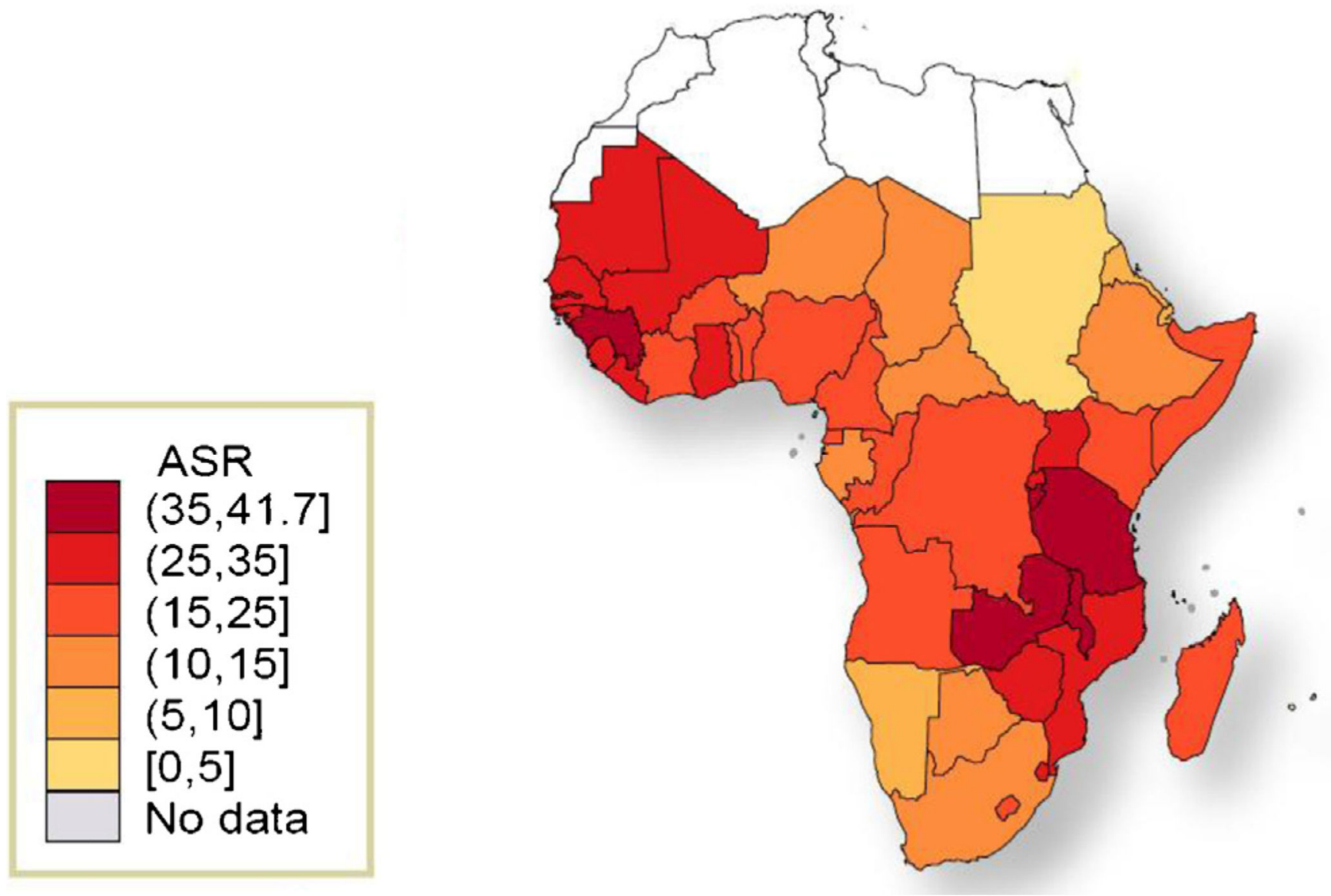

Fig. 3.

Age-standardized mortality rates of cervical cancer in sub-Saharan Africa region. Adapted from GLOBOCAN 2008 [2]. ASR: Age-standardized mortality rate, per 100,000 women and year (all ages). 


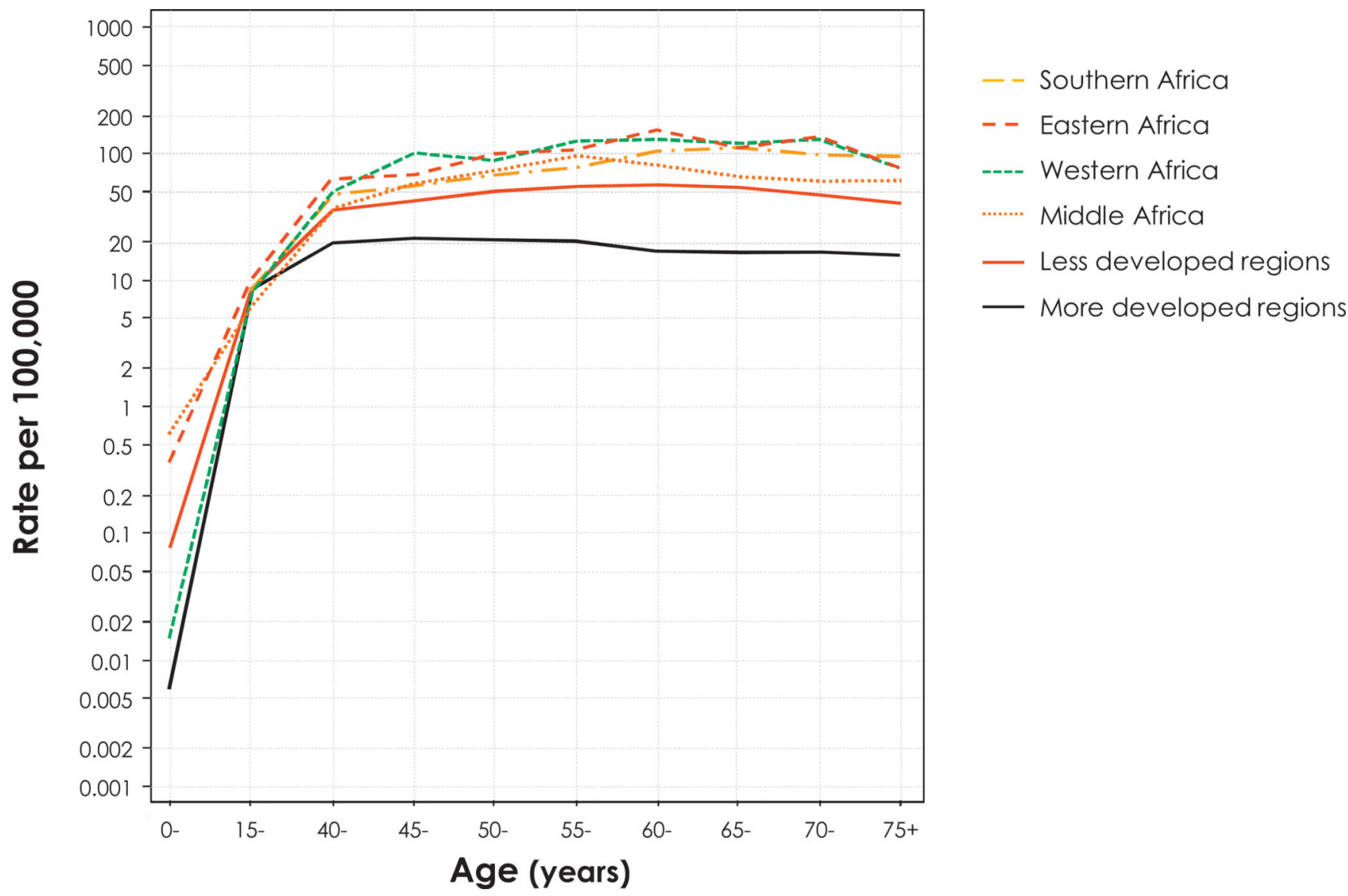

Fig. 4.

Age-specific incidence rates of cervical cancer in the sub-Saharan Africa region, and less or more developed regions. Data source: GLOBOCAN 2008 [2]. 

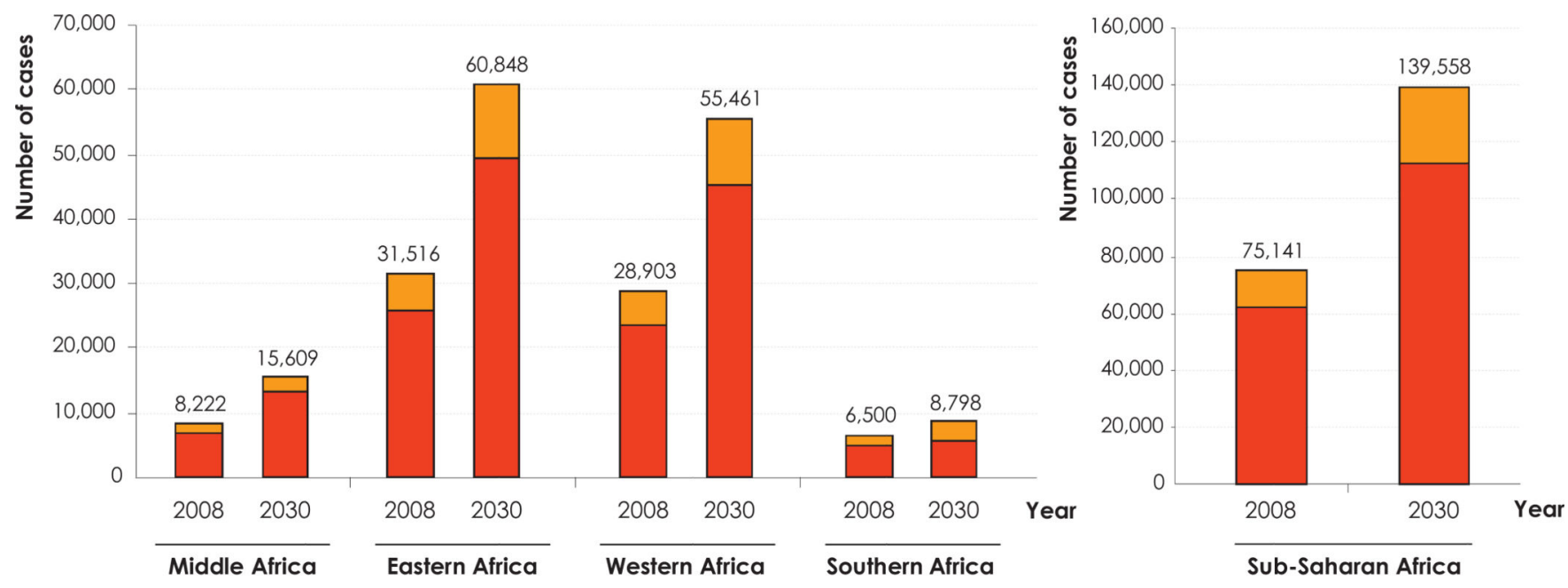

Fig. 5.

Estimated number of new cases of cervical cancer in the sub-Saharan Africa region by age groups, in 2008, and projected in 2030. Data source: GLOBOCAN 2008 [2]. 


\section{a) for cervical cancer by regions}

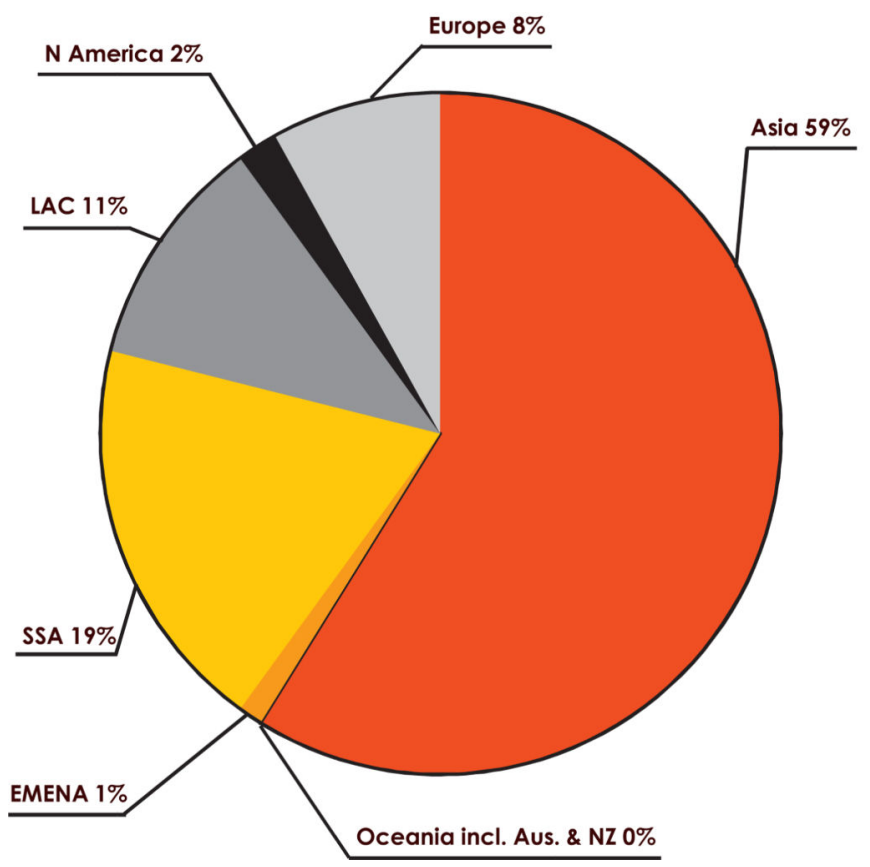

\section{b) for sub-Saharan Africa region by type of cancer}

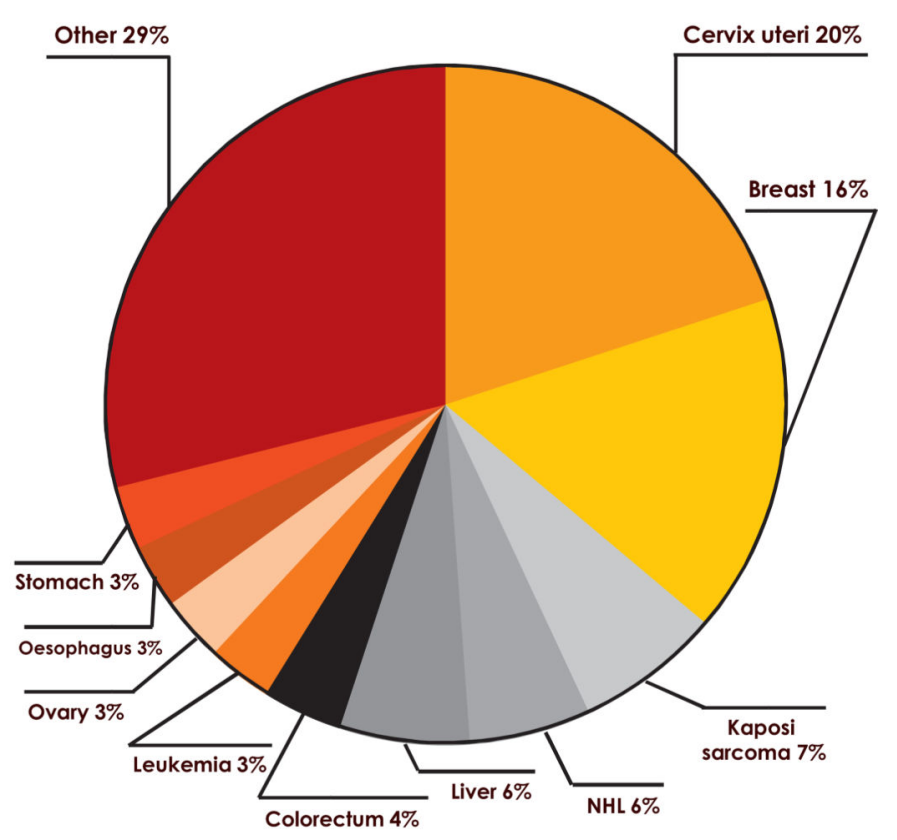

Fig. 6.

Estimated years of life lost in 2008: (a) for cervical cancer by regions (b) for the sub-

Saharan Africa region by type of cancer. Data from Saint Helena, Säo Tomé and Principe, Seychelles and South Sudan were unavailable in GLOBOCAN 2008 [2]. EMENA:

Extended Middle East and North Africa; LAC: Latin America and Caribbean; N America: North America; NHL: Non-Hodgkin Lymphoma; Oceania incl. Aus. \& NZ: Oceania including Australia and New Zealand; SSA: Sub-Saharan Africa. 


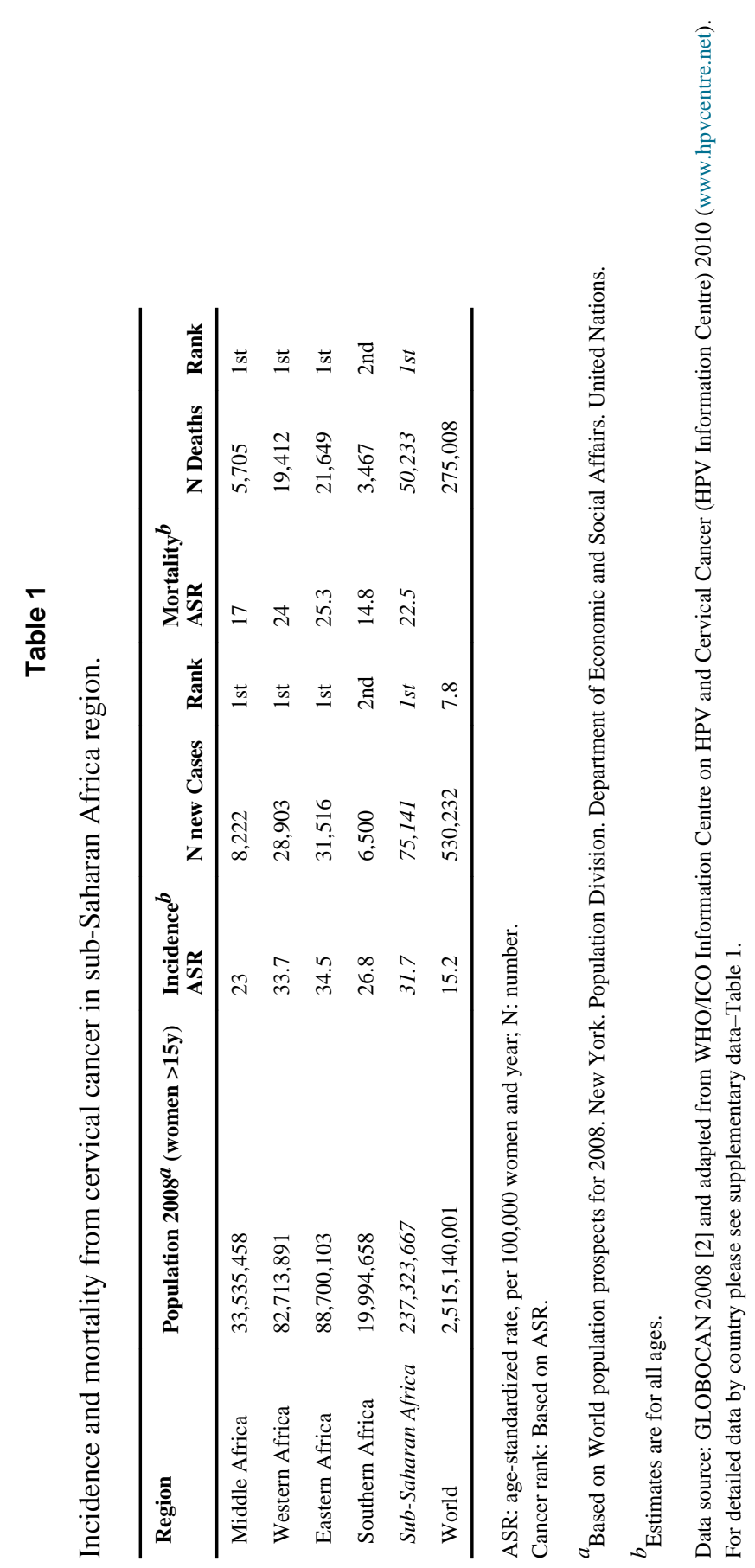


Table 2

Trends in incidence of cervical cancer in selected cancer registries.

\begin{tabular}{llll}
\hline Cancer registry & N cases & Crude Rate & ASR \\
\hline Mali, Bamako & & & \\
Vol 6 - 1987-1989 & 124 & 12.2 & 23.4 \\
Vol 7 - 1988-1992 & 248 & 14.8 & 29.1 \\
Vol 8 - 1994-1996 & 182 & 15.9 & 35.9 \\
Uganda, Kyadondo (Kampala) & & & \\
Vol 7 - 1991-1993 & 248 & 15.6 & 40.8 \\
Vol 8 - 1993-1997 & 465 & 16.1 & 41.7 \\
Vol 9 - 1998-2002 & 649 & 16.4 & 45.8 \\
Zimbabwe, Harare & & & \\
Vol 7 - 1990-1992 & 295 & 19.5 & 64.8 \\
Vol 8 - 1993-1997 & 613 & 19.1 & 55.0 \\
Vol 9 - 1998-2002 & 818 & 18.8 & 47.3 \\
\hline
\end{tabular}

ASR: age-standardized incidence rate, per 100,000 women and year (all ages); N: number. Data source: Cancer Incidence in Five Continents [3]. 
\&.

$\Xi \quad \frac{2}{z}$

3

3. 运

$\stackrel{\square}{\circ} \quad \frac{n}{z}$

$\therefore \quad \frac{\pi}{z}$

$\therefore \quad \tilde{z}$

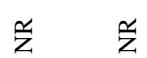

3. $\frac{\pi}{2}$

こ ₹

दे के

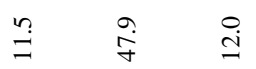

ฉू

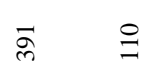

\&

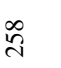

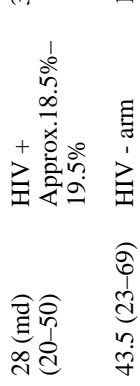

in है

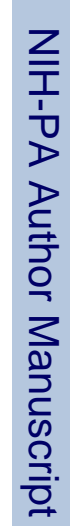

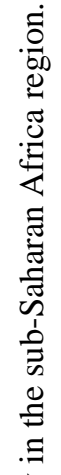

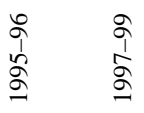

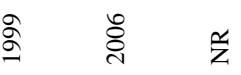

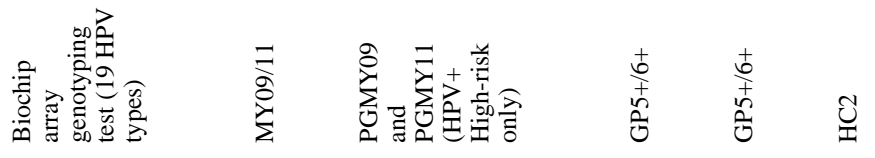

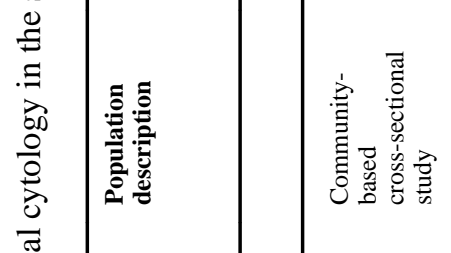

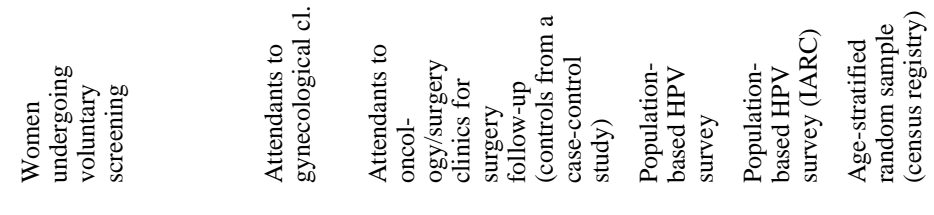

带

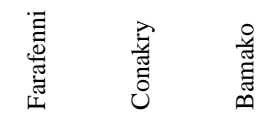

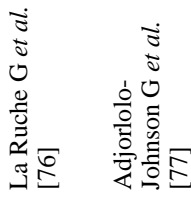

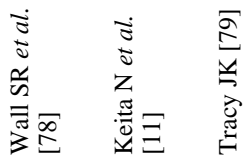

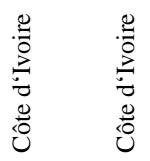

总产总 


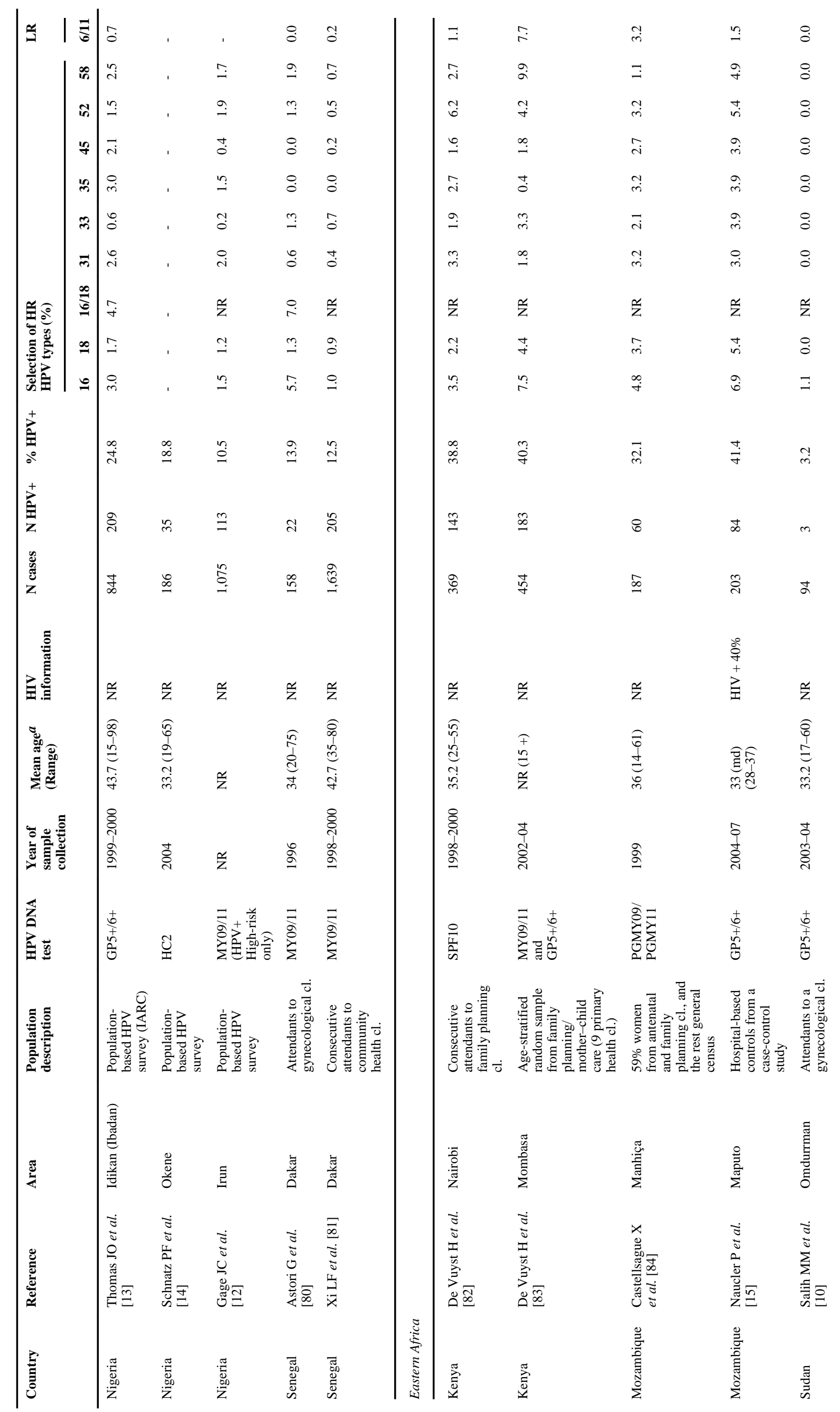


<smiles>C1CCCCC1</smiles> 


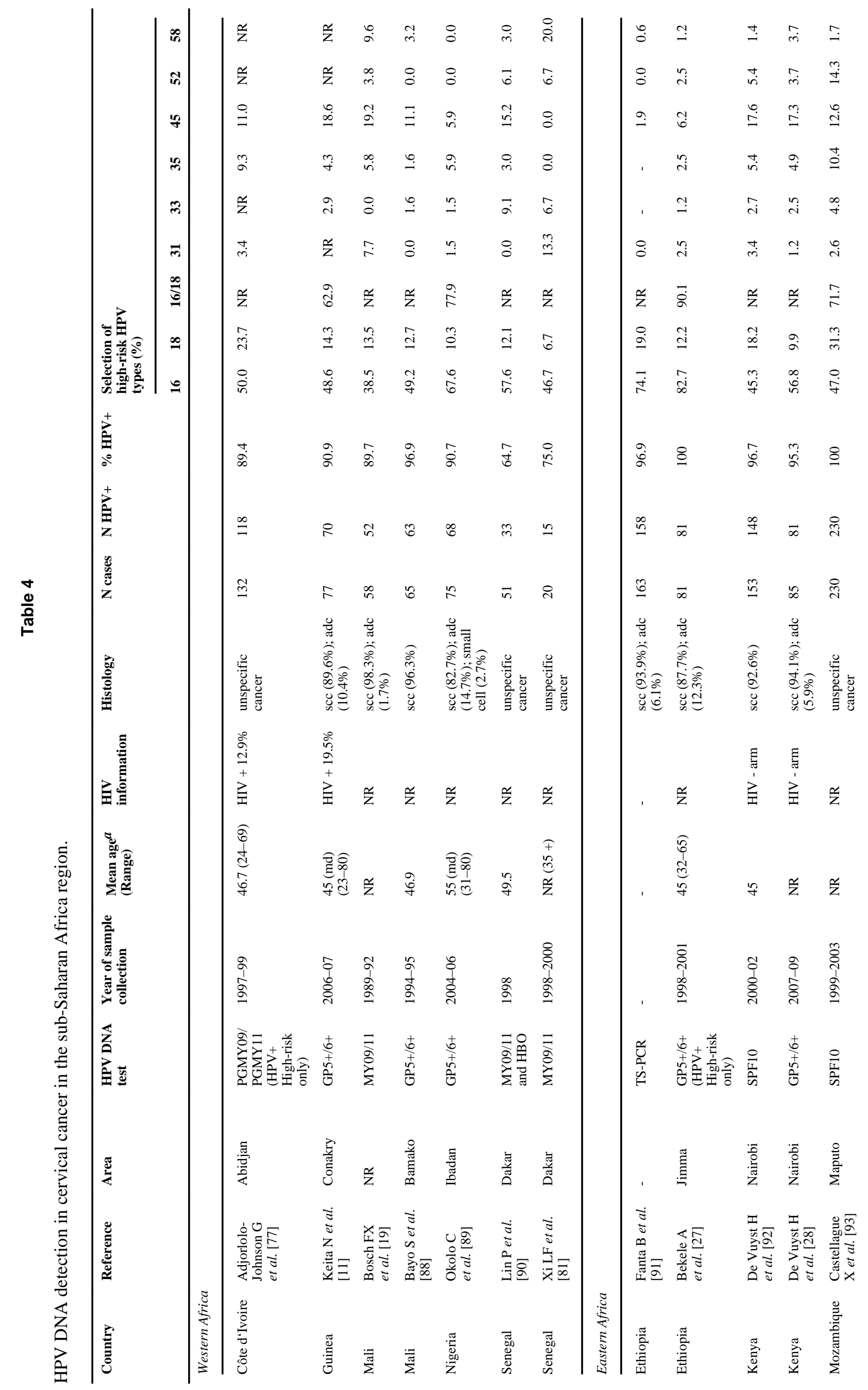




\section{Table 5}

Incidence of vulvar, vaginal, penile and anal cancer in selected cancer registries during 1998-2002.

\begin{tabular}{llll}
\hline Cancer & N cases & Crude Rate & ASR \\
\hline Vulvar cancer & & & \\
Uganda, Kyadondo County & 7 & 0.2 & 0.3 \\
Zimbabwe, Harare & 16 & 0.4 & 0.7 \\
Vaginal cancer & & & \\
Uganda, Kyadondo County & 6 & 0.2 & 0.6 \\
Zimbabwe, Harare & 6 & 0.1 & 0.3 \\
Penile cancer & & & \\
Uganda, Kyadondo County & 25 & 0.7 & 2.8 \\
Zimbabwe, Harare & 19 & 0.4 & 0.9 \\
Anal cancer, Women & & & $<0.1$ \\
Uganda, Kyadondo County & 3 & $<0.1$ & $<0.1$ \\
Zimbabwe, Harare & 2 & $<0.1$ & \\
Anal cancer, Men & & & 0.2 \\
Uganda, Kyadondo County & 2 & $<0.1$ & \\
Zimbabwe, Harare & 4 & $<0.1$ & \\
\hline
\end{tabular}

ASR: Age-standardized incidence rate, per 100,000 women and year (all ages); N: number. Data source: Cancer Incidence in Five Continents [3] 


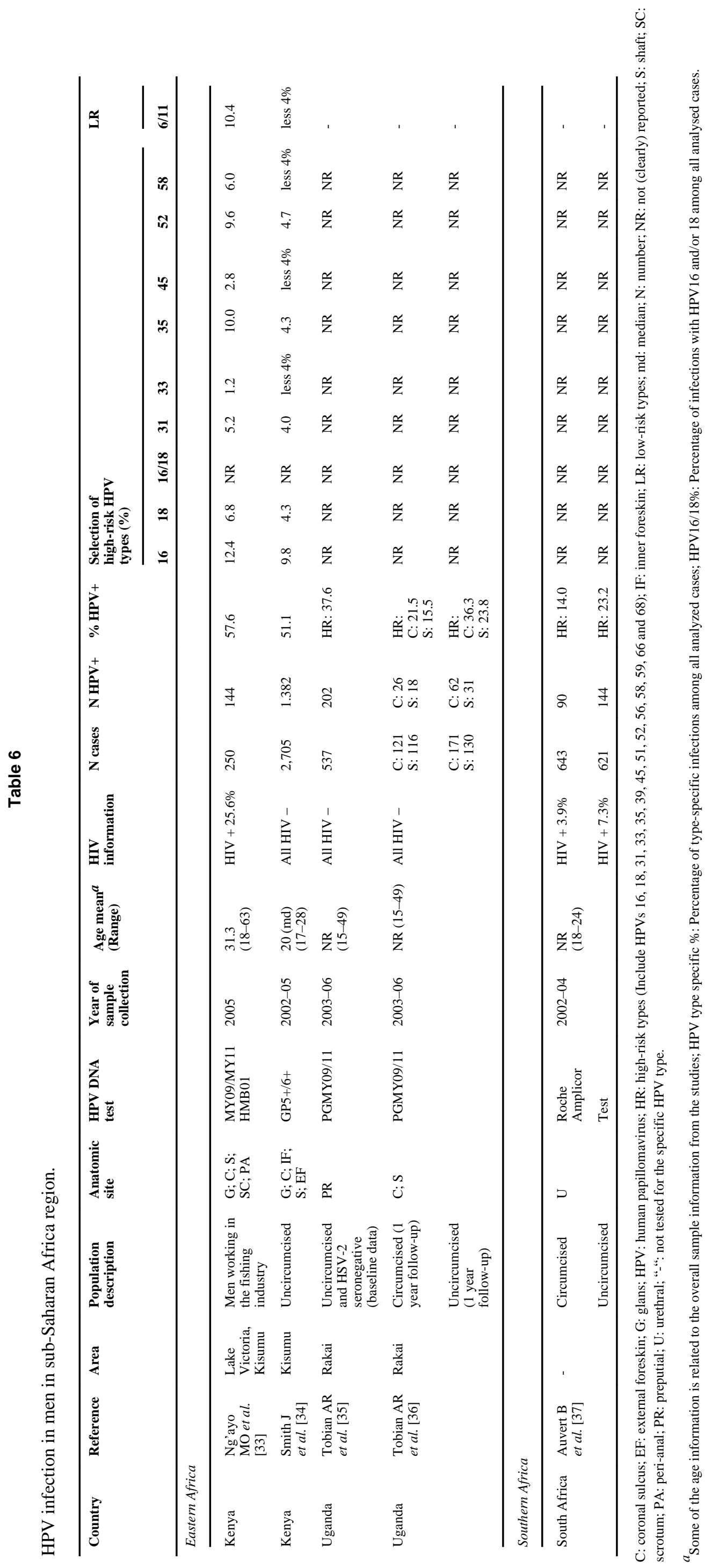

